\title{
Implementation of an aerosol-cloud-microphysics-radiation coupling into the NASA unified WRF: Simulation results for the 6-7 August 2006 AMMA special observing period
}

\author{
J. J. Shi, ${ }^{\mathrm{a}, \mathrm{b} *}$ T. Matsui, ${ }^{\mathrm{a}, \mathrm{c}}$ W.-K. Tao, ${ }^{\mathrm{a}} \mathrm{Q}$. Tan, ${ }^{\mathrm{a}, \mathrm{d}}$ C. Peters-Lidard, ${ }^{\mathrm{a}}$ M. Chin, ${ }^{\mathrm{a}}$ K. Pickering, ${ }^{\mathrm{a}}$ \\ N. Guy, ${ }^{\text {e }}$ S. Lang ${ }^{\mathrm{a}, \mathrm{f}}$ and E. M. Kemp ${ }^{\mathrm{a}, \mathrm{e}}$ \\ ${ }^{a}$ NASA Goddard Space Flight Center, Greenbelt, MD, USA \\ ${ }^{\mathrm{b}}$ Goddard Earth Sciences Technology and Research, Morgan State University, Baltimore, MD, USA \\ ${ }^{\mathrm{c}}$ Earth System Science Interdisciplinary Center, University of Maryland, College Park, MD, USA \\ ${ }^{\mathrm{d}}$ Universities Space Research Association, Columbia, MD, USA \\ ${ }^{\mathrm{e}}$ NOAA National Severe Storms Laboratory, Norman, OK, USA \\ ${ }^{\mathrm{f}}$ Science Systems and Applications Inc., Lanham, MD, USA
}

*Correspondence to: Jainn J. Shi, NASA Goddard Space Flight Center, Greenbelt, MD 20771, USA. E-mail: jainn.j.shi@nasa.gov

Aerosols affect the Earth's radiation balance directly and cloud microphysical processes indirectly via the activation of cloud condensation and ice nuclei. These two effects have often been considered separately and independently, hence the need to assess their combined impact given the differing nature of their effects on convective clouds. To study both effects, an aerosol-microphysics-radiation coupling, including Goddard microphysics and radiation schemes, was implemented into the NASA Unified Weather Research and Forecasting model (NU-WRF). Fully coupled NU-WRF simulations were conducted for a mesoscale convective system (MCS) that passed through the Niamey, Niger area on 6-7 August 2006 during an AMMA special observing period. The results suggest that rainfall is reduced when aerosol indirect effects are included, regardless of the aerosol direct effect. Daily mean radiation heating profiles in the area traversed by the MCS showed the aerosol (mainly mineral dust) direct effect had the largest impact near cloud tops just above $200 \mathrm{hPa}$ where short-wave heating increased by about $0.8 \mathrm{~K} \mathrm{day}^{-1}$; the weakest long-wave cooling was at around $250 \mathrm{hPa}$. It was also found that more condensation and ice nuclei as a result of higher aerosol/dust concentrations led to increased amounts of all cloud hydrometeors because of the microphysical indirect effect, and the radiation direct effect acts to reduce precipitating cloud particles (rain, snow and graupel) in the middle and lower cloud layers while increasing the non-precipitating particles (ice) in the cirrus anvil. However, when the aerosol direct effect was activated, regardless of the indirect effect, the onset of MCS precipitation was delayed about $2 \mathrm{~h}$, in conjunction with the delay in the activation of cloud condensation and ice nuclei. Overall, for this particular environment, model set-up and physics configuration, the effect of aerosol radiative heating due to mineral dust overwhelmed the effect of the aerosols on microphysics.

Key Words: WRF; AMMA; aerosol; micropysics; radiation

Received 13 March 2013; Revised 26 July 2013; Accepted 28 October 2013; Published online in Wiley Online Library 12 February 2014

\section{Introduction}

It is well known that aerosols are a critical factor in the atmospheric hydrological cycle and radiation budget. Aerosols affect weather and climate in many ways, both as a major agent for cloud formation and through the extinction of solar radiation. Aerosols have a direct effect on how long-wave and short-wave radiation are absorbed and scattered in the atmosphere and consequently the heating in the atmosphere and at the surface
(Carlson and Benjamin, 1980; Fouquart et al., 1987; Ackerman and Chung, 1992; Li et al., 2004; Zhu et al., 2007; Brindley and Russell, 2008, 2009; Mallet et al., 2009; Stanelle et al., 2010). Atmospheric heating and cooling at the Earth's surface caused by the absorption of aerosols are hypothesized to have significant climate impacts, especially mineral dust aerosols, which are a critical absorbing constituent in many places, including North Africa (Wang et al., 2009). Perturbations in atmospheric heating can modulate atmospheric dynamics and thus cloud-precipitation 
formulation. Lau and Kim (2006) proposed an elevated heat pump hypothesis. They found that anomalously high concentrations of absorbing aerosols during the pre-monsoon season are associated with anomalous warming associated with increased heating of the upper troposphere over the Tibetan Plateau in April-May and subsequent increased rainfall over the Indian subcontinent and decreased rainfall over East Asia in June-July. Most of the previous studies on the impact of aerosols on radiation were directed at climate or seasonal effects; there was no study examining the impact on mesoscale convective systems (MCSs), which have relatively short life spans of 2-3 days. Recently, Chen et al.(2010) developed a tracer model based on the Weather Research and Forecasting model (WRF) to study the effects of dust/radiation on the modification of the Saharan Air Layer (SAL) and its environment, which can influence tropical cyclone (TC) activity over the Atlantic Ocean. Dust processes due to advection, boundary-layer mixing, cumulus mixing, dry sedimentation, and dust-radiation interaction were included in their model. They found that dust-radiation interactions mainly warmed the dusty layer between 750 and $550 \mathrm{hPa}$, which increased the vertical wind shear south of the SAL where easterly disturbances and TCs usually occur. However, their modelling study did not consider moist deposition nor aerosol-microphysics interactions such as the impact of dust on the formation of ice crystals. Johnson et al.(2008) suggested that the magnitude of short-wave radiation effects was sensitive to the vertical distribution of aerosols, especially the vertical distribution of absorbing aerosols. This heating in turn changes the atmospheric stability and thereby convective and turbulent motions as well as cloud formulation.

On the other hand, these same aerosols also often serve as cloud condensation nuclei $(\mathrm{CCN})$ in the formation of cloud droplets as well as ice nuclei (IN) in the formation of ice particles. As a result, aerosols acting as CCN and IN exert considerable influence on the microphysical properties of both warm and ice clouds. Recent research efforts have led to notable progress in our understanding of their microphysical properties and the factors that enable them to act as CCN and IN and therefore the indirect effect on cloud formation (Levin and Cotton, 2009; Tao et al., 2012). However, the various mechanisms behind these effects, in particular the ones connected to precipitation, are not yet well understood, especially in MCSs with their relatively short 2-3 day life cycles. There have been many numerical studies on the effect of aerosols on the dynamics and microphysics of individual deep convective clouds and cloud ensembles (Khain et al., 2009; Levin and Cotton, 2009; Tao et al., 2012). Levin and Cotton (2009) concluded that simulations of aerosol-cloud interactions should be done at the appropriate scale so that the development of cloud supersaturation, droplet activation, and growth processes are resolved. In most studies, convective invigoration accompanied by an increase in the amount of supercooled water at higher levels has been reported with increasing aerosol concentrations. Regarding the effects on precipitation, increased precipitation with increasing aerosol concentration was reported in simulations of maritime convective clouds and clouds developing in a moist subtropical atmosphere. For more continental/drier conditions, however, decreased precipitation with increasing aerosol concentration has been reported (Khain et al., 2009). Tao et al.(2012) also stated that it is also commonly held that a clean environment with a low CCN concentration produces fewer droplets of larger size due to greater condensation and collectional growth as compared to a high CCN environment. There have been many three-dimensional (3-D) simulations using a mesoscale model like the PSU/NCAR Mesoscale Model (MM5) (Lynn et al., 2007) and WRF (Khain and Lynn, 2009; Khain et al., 2009, 2010) as well as cloud-resolving models or CRMs (Tao et al., 2007; Li et al., 2008, 2009). As shown in table 3 of Tao et al.(2012), these simulations used either a two-moment bulk scheme or a spectral bin model (SBM) as described in Khain et al.(2004), which is very computing intensive and requires substantial computer resources. The recent modelling study by
Smoydzin et al.(2012) showed that the presence of mineral dust can increase the formation of ice crystals and shift the spatial and temporal precipitation pattern while the impact of mineral dust acting as giant cloud condensation nuclei on precipitation was found to be small. They also found the presence of mineral dust did not change the total amount of precipitation much. However, none of these studies included the direct effect of aerosols on radiation. Rosenfeld et al. (2008) suggested that aerosol radiative and microphysical effects on weather systems have usually been considered separately and independently and that there is a need to study them together given the opposing microphysical and radiative effects aerosols have on deep warm-base convective clouds. Bangert et al.(2012) used a non-hydrostatic model with both aerosol radiative and microphysical effects to simulate a strong Saharan dust event over western Europe and found that mineral dust particles had a significant impact on clouds between the freezing level and the level of homogeneous freezing but a much smaller impact on cloud droplet number concentration. They also concluded that the magnitude of the temperature change due to the aerosol direct radiative effect was enough to explain a systematic bias in numerical weather prediction during the event.

The African Monsoon Multidisciplinary Analysis (AMMA, $\mathrm{http}$ ://amma-international.org/) project is an international research programme that aims to improve our knowledge and understanding of the West African Monsoon (WAM) and investigate its variability and influence on the regional water resources (Lebel et al., 2009). Detailed meteorological descriptions for the AMMA field experiment have been given by Janicot et al.(2008) and Ruti et al.(2011). These are the most detailed measurements ever performed in this region. One of the key issues was to investigate MCSs and their linkage to WAM variability. MCSs typically provide the majority of precipitation over West Africa during the WAM (June-September) (Le Barbé and Lebel, 1997; D'Amato and Lebel, 1998; Laurent et al., 1998; Mathon et al., 2002; Redelsperger et al., 2002; Fink et al., 2006). Numerical weather prediction models have usually performed poorly in re-producing the characteristics of the WAM (Ruti et al., 2011). The synoptic situation in the AMMA area is dominated by the WAM between July and mid-August (Parker et al., 2005; Nicholson, 2009). The onset of the WAM in the region usually starts with a latitudinal shift of the intertropical convergence zone (ITCZ) from $5^{\circ} \mathrm{N}$ to $10^{\circ} \mathrm{N}$. Typically, there is a strong thermal gradient between the heated tropical and subtropical mainland over the Sahara Desert and the cooler Gulf of Guinea and South Atlantic Ocean. The confluence zone in the lower troposphere between this relatively cool, moist southwesterly flow and the hot, dry northeasterly flow from the Sahara is often called the intertropical discontinuity (ITD) or intertropical front (ITF) (Thorncroft and Haile, 1995; Huntrieser et al., 2011). Historically, it has been extremely difficult to archive a good MCS simulation for this region as the initial and boundary conditions from the global analyses (e.g. National Centers for Environmental Prediction Global Forecast System (NCEP GFS) or ECMWF ReAnalysis (ERA-Interim)) covering this area are not as reliable as those covering other parts of the world. Penide et al.(2010) was able to simulate an MCS during the AMMA Special Observing Period (SOP) on 7-9 September 2006 using BRAMS (the Brazilian Regional Atmospheric Modelling System). In their study, the MCS was correctly situated in space but was $2 \mathrm{~h}$ too late. Powell et al.(2012) were also able to use WRF at high resolution to simulate cloud systems in the region during the summer of 2006. However, they only presented statistical results from their simulations and did not reveal how well the cloud systems were simulated in terms of timing and location.

This study describes the implementation of an inline coupling of aerosols, microphysics and radiation into a mesoscale modelling system as suggested by Rosenfeld et al.(2008) and the subsequent simulations conducted for conditions observed on 6-7 August 2006, which occurred during an AMMA SOP 
and are described briefly in section 2. A brief review of the National Aeronautics and Space Administration (NASA) Unified WRF (NU-WRF), the Goddard physical packages, the satellite simulators and the Goddard Chemistry Aerosol Radiation and Transport model (GOCART) in WRF-Chem is given in section 3. In section 4, details of the aerosol-cloud-microphysics-radiation coupling are discussed. In section 5, the model set-up and simulation designs are provided. In section 6 , results from the high-resolution NU-WRF simulations are compared with in situ and satellite observations, including the observed reflectivities collected with the $\mathrm{C}$-band, single polarization Massachusetts Institute of Technology (MIT) Doppler radar located in Niamey, Niger and the infrared (IR) brightness temperatures observed by Meteosat. The aerosol direct (radiation) and indirect (microphysics) effects on the MCS are also discussed in section 6. A summary and discussion are given in section 7 .

\section{Synoptic conditions during the AMMA SOP on 5-6 August 2006}

As seen from the European Centre for Medium-range Weather Forecasts (ECMWF) Interim Reanalysis (ERA-Interim) data (Dee et al., 2011), there was a strong $850 \mathrm{hPa}$ confluence zone over northeastern Niger (around $12^{\circ} \mathrm{W}$ and $20^{\circ} \mathrm{N}$ ) on 1800 UTC 5 August 2006 that persisted over the next $24 \mathrm{~h}$ (Figure 1). An extended, circular cloud band started forming in central Niger around 1800 UTC on 5 August before gradually moving southwestward. The cloud band became elongated with a northwest-southeast orientation around 0000 UTC 6 August. The MCS chosen for this study swept through southwestern Niger on 6 August 2006. The system was well organized with deep convective clouds accompanied by stratiform clouds and nonprecipitating anvil ice clouds. Meteosat images of IR brightness temperatures (Tbs) associated with the MCS (IR Tbs below $-65^{\circ} \mathrm{C}$ are highlighted in orange) every $6 \mathrm{~h}$ starting at 1200 UTC 5 August 2006 are shown in Figure 2. The MCS passed Niamey, Niger from the east on the morning of 6 August and proceeded rapidly westward $\left(\sim 15 \mathrm{~m} \mathrm{~s}^{-1}\right)$ (Huntrieser et al., 2011). After passing Niamey at $\sim 0830$ UTC, the system entered the decaying stage before completely dissipating at 1800 UTC 6 August 2006 after moving out of Niger. The structure of this cloud band was characterized well by the MIT C-band radar at Niamey as well as the CloudSat and Tropical Rainfall Measuring Mission (TRMM) satellites.

The CloudSat satellite descended southeastward over the cloud band at $\sim 1341$ UTC 6 August 2006, obtaining a northwest-southeast vertical cross-section of attenuating Wband radar reflectivity through the MCS. The vertical crosssection from CloudSat shows that the MCS had an anvil that extended on the order of around $400 \mathrm{~km}$. As the MCS was propagating westward over the radar (Figure 7), it had a northwest-southeast orientation and exhibited clear leading and trailing anvils as seen in the CloudSat vertical cross-section (Figure 3). The overall cloud band expanded to over $\sim 500 \mathrm{~km}$ $\left(12-17^{\circ} \mathrm{N}\right)$ in a north-south direction and over $\sim 300-400 \mathrm{~km}$ (around $0-4^{\circ} \mathrm{E}$ ) in an east-west direction with cloud tops reaching up to $\sim 13 \mathrm{~km}$ (Huntrieser et al., 2011). Huntrieser et al.(2011) also mentioned that the height of the cold point tropopause was $16 \mathrm{~km}(\sim 100 \mathrm{hPa})$ while ECMWF wind analyses indicate that the core (maximum of $18 \mathrm{~m} \mathrm{~s}^{-1}$ ) of the African Easterly Jet (AEJ) was located slightly north of the cloud band, between 15 and $20^{\circ} \mathrm{N}$, at an altitude of between 700 and $500 \mathrm{hPa}$.

\section{Brief review of NU-WRF and the GOCART in WRF-Chem}

\subsection{NASA Unified WRF (NU-WRF)}

WRF is a next-generation mesoscale forecast model and assimilation system. The development of WRF has been a multi-agency effort led by the National Center for Atmospheric
Research (NCAR) with several National Oceanic and Atmospheric Administration (NOAA) and Department of Defense (DOD) partners. The model is designed to support research advancing the understanding and prediction of mesoscale precipitation systems. It incorporates advanced numerics and data assimilation techniques, a multiple relocatable nesting capability, and improved physics. WRF has been used for a wide range of applications, from idealized research to operational forecasting, with an emphasis on horizontal grids in the range of $1-10 \mathrm{~km}$. Its spectrum of physics and dynamics options reflects the experience and input of the broad scientific community (Michalakes et al., 2004). There are two dynamics solvers in the WRF Software Framework (WSF): the Advanced Research WRF (ARW) solver (originally referred to as the Eulerian mass or 'em' solver) developed primarily at NCAR and the Nonhydrostatic Mesoscale Model (NMM) solver developed at NCEP. Detailed documentation on WRF and the WSF can be found in Skamarock et al. (2008). NU-WRF is based on WRF-ARW version 3.2.1 with the addition of several Goddard physics packages (microphysics, chemistry, radiation, and land-surface hydrology processes) and a real-time forecast system, which can be driven by initial and boundary conditions from global analyses like NCEP's GFS, NASA's GEOS5/MERRA (Goddard Earth Observing System model Version 5/Modern-Era Retrospective analysis for Research and Applications) and ECMWF's ERA-Interim and from mesoscale analyses like NCEP's NAM (North America Mesoscale) model. NU-WRF includes the following Goddard modules (Figure 4(a)).

\subsubsection{One-moment bulk microphysics scheme}

The Goddard Microphysics scheme is the same as the one used in the Goddard Cumulus Ensemble (GCE) model and is mainly based on Lin et al.(1983) with additional processes from Rutledge and Hobbs (1984). The Goddard microphysical scheme is a two-class liquid and three-class ice scheme with four different options: 3ICE-graupel, 3ICE-hail, and 2ICE (only cloud ice and snow) and warm rain only (no ice). Major features include: (i) the option to choose either graupel or hail as the third class of ice (McCumber et al., 1991). Graupel has a relatively low density and large intercept (i.e. high number concentration) and hail a high density and relatively small intercept (i.e. low number concentration). These differences can affect not only the description of the hydrometeor population, but also the relative importance of the microphysical-dynamical-radiative processes; (ii) this saturation technique is basically designed to ensure that supersaturation (subsaturation) does not exist at a grid point that is clear (cloudy) and is one of the last microphysical processes to be computed, prior only to rain evaporation and snow/graupel/hail deposition or sublimation; and (iii) all microphysical processes (transfer rates from one type of hydrometeor to another) that do not involve melting, evaporation and sublimation, are calculated based on one thermodynamic state. Details of the Goddard microphysical scheme can be found in Tao et al.(2003). Recently, the Goddard microphysics scheme has been modified to reduce overestimated and unrealistic amounts of cloud water and graupel in the stratiform region (Lang et al., 2007, 2011; Shi et al., 2010).

\subsubsection{Long-wave (LW) and short-wave (SW) radiation schemes}

The Goddard radiation schemes have been developed over the past two decades at NASA Goddard for use in general circulation models (GCMs), regional models and CRMs (Chou and Suarez, 1999, 2001). A few recent improvements were made to the Goddard radiation package before it was added into WRF: (i) the short-wave radiation code was optimized for computational speed (improved by a factor of 2); (ii) cloud optical properties were made to be consistent with the assumptions in the Goddard microphysics; (iii) stratospheric layers can be optionally added above the top model pressure level; and (iv) the aerosol direct 
(a)

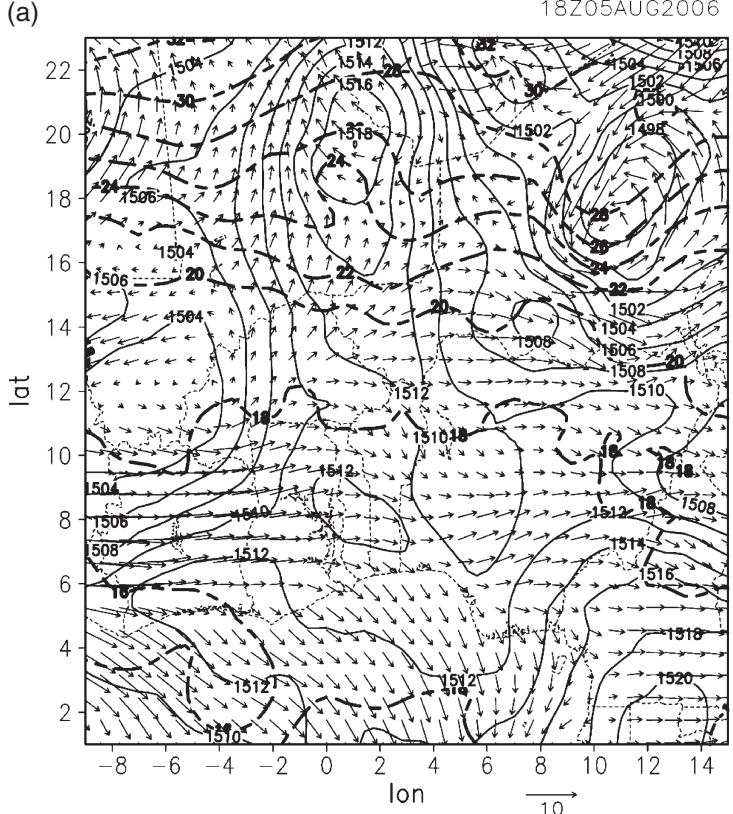

(c)

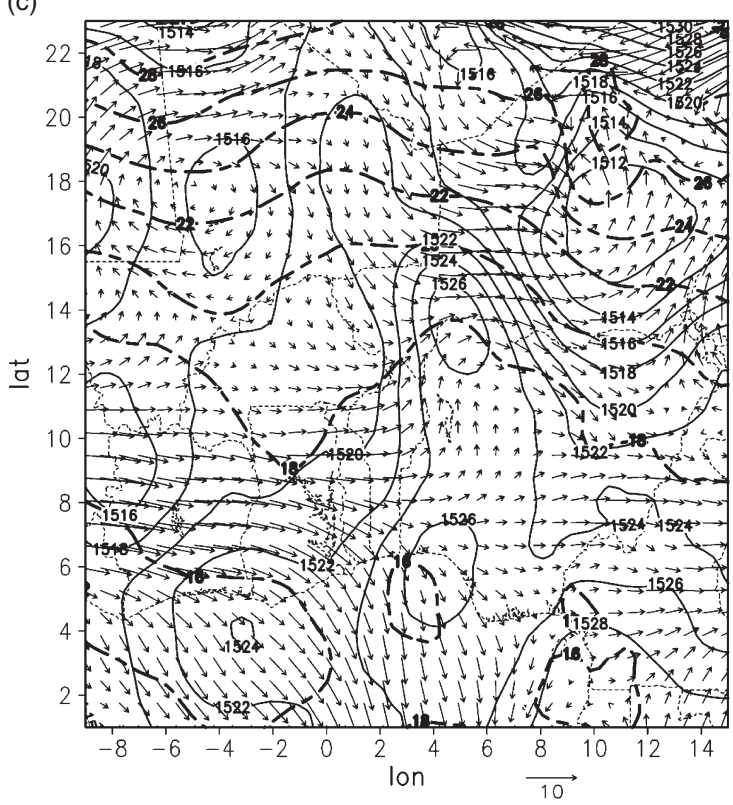

(e)

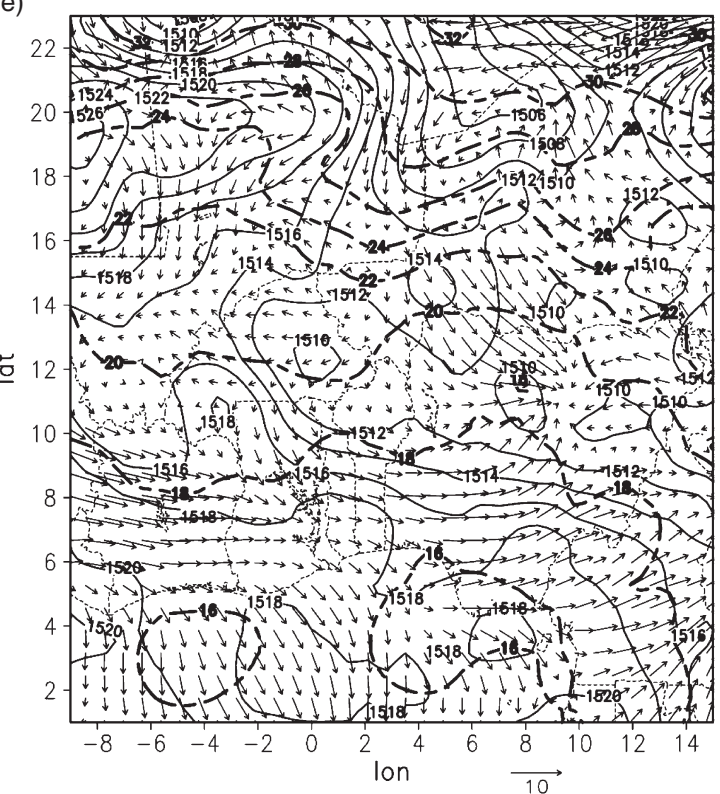

(b)

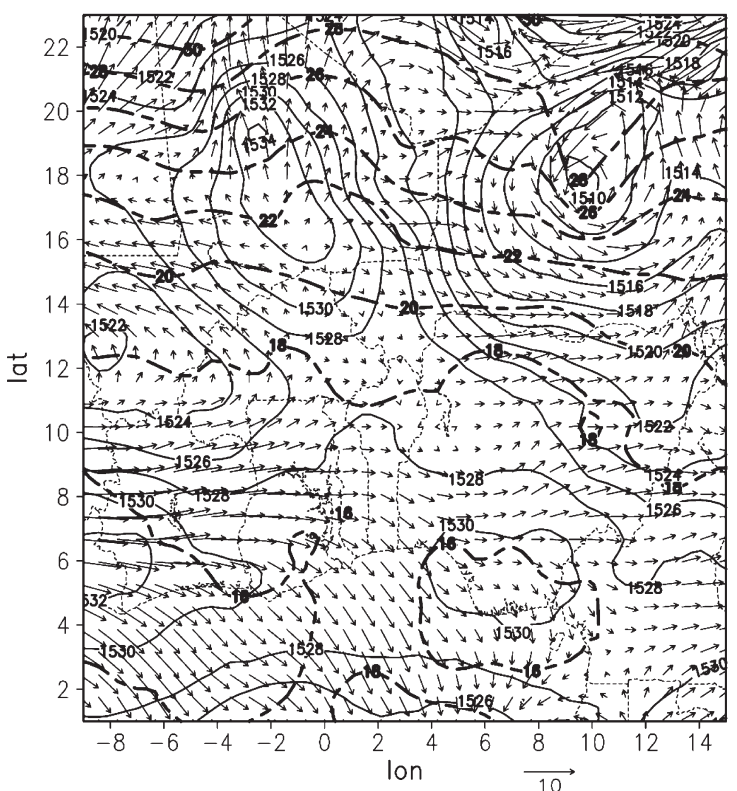

(d)

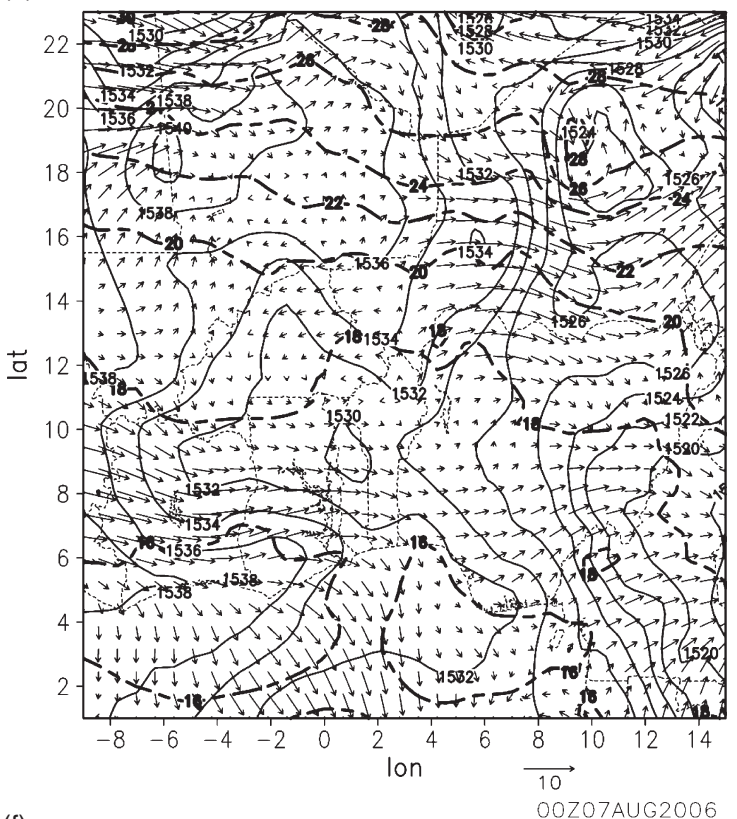

(f)

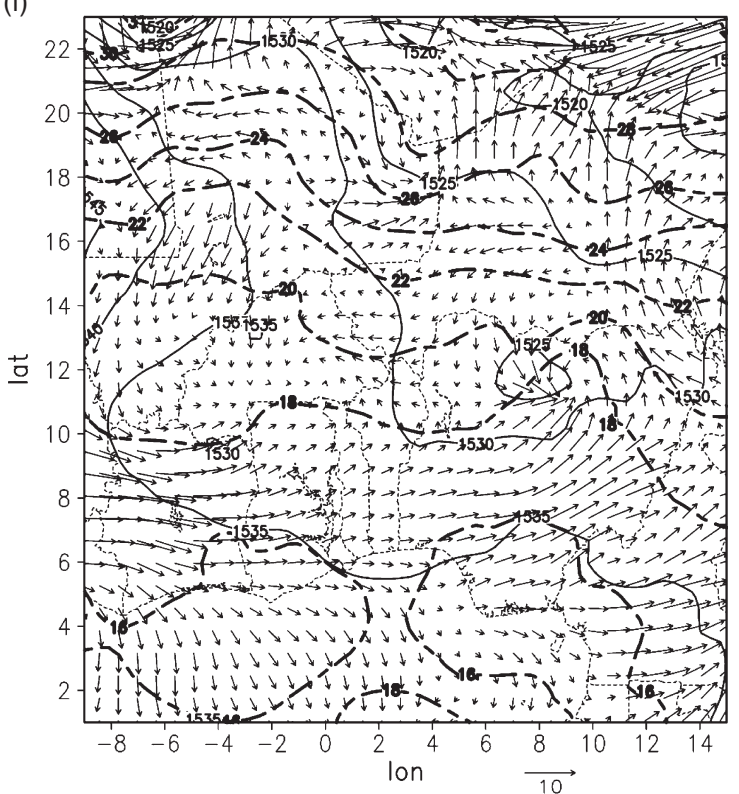

Figure 1. $850 \mathrm{hPa}$ heights ( $\mathrm{m}$, solid contours), temperatures $\left({ }^{\circ} \mathrm{C}\right.$, dashed lines) and wind vectors $\left(\mathrm{m} \mathrm{s}^{-1}\right)$ from ERA-Interim reanalysis data every $6 \mathrm{~h}$ starting at 1800 UTC 5 August 2006. 


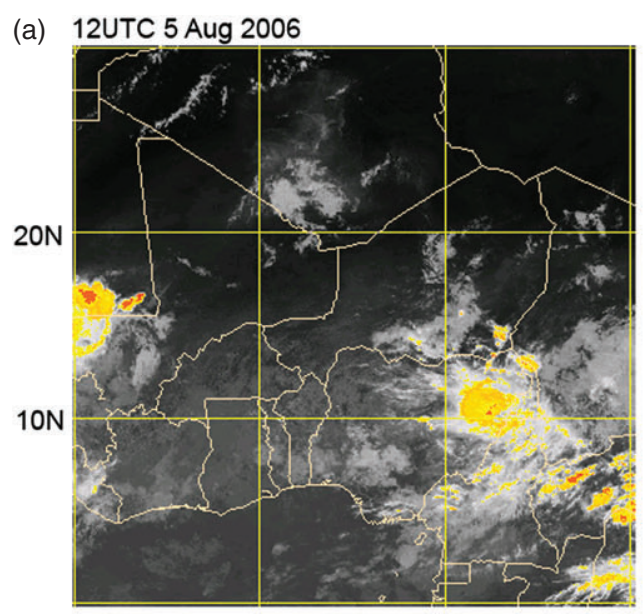

OE
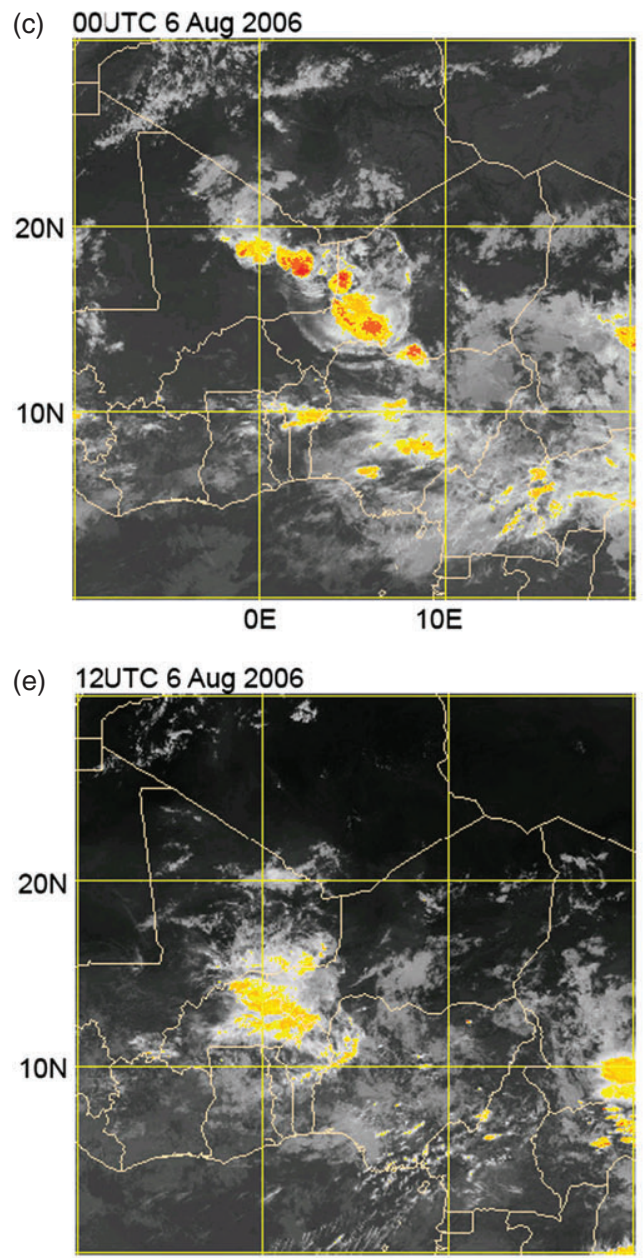

OE

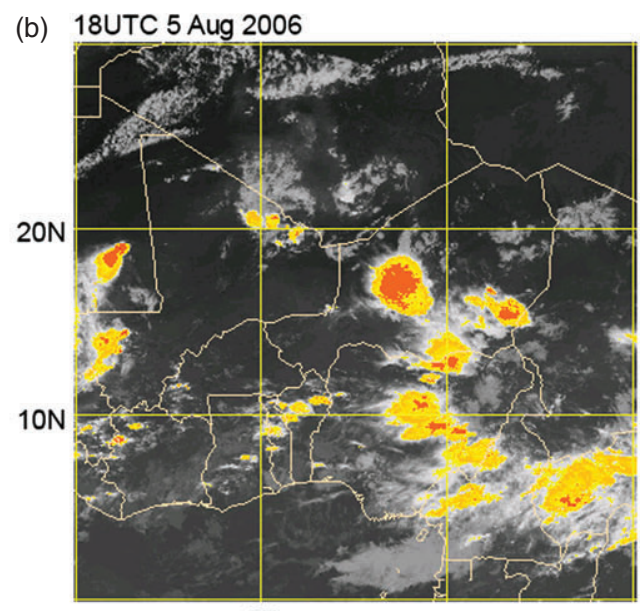

OE

(d) 06UTC 6 Aug 2006

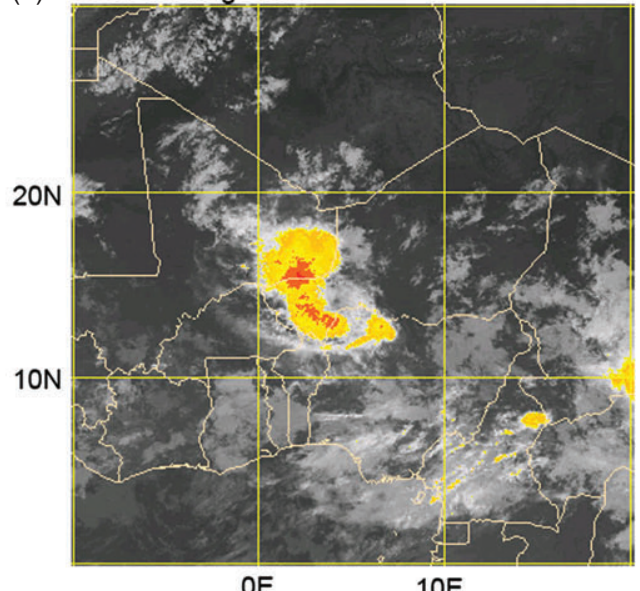

OE

(f) 18 UTC 6 Aug 2006

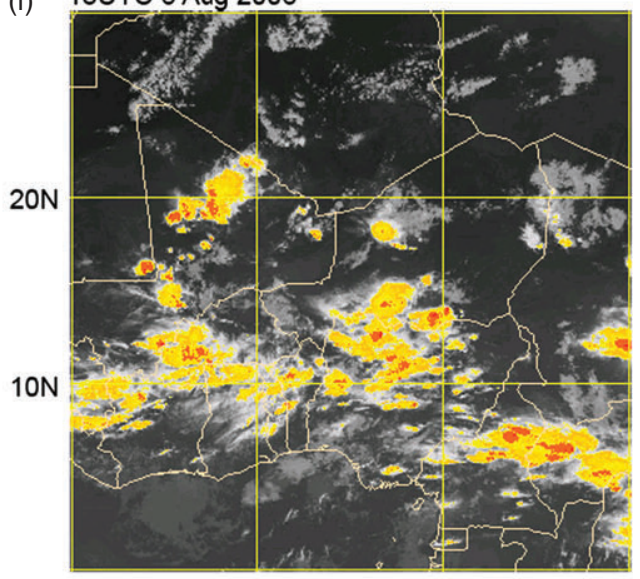

OE

$10 E$

Figure 2. Meteosat infrared (IR) brightness temperatures (Tbs) with Tbs below $-65^{\circ} \mathrm{C}$ enhanced in orange (for identifying MCS) every $6 \mathrm{~h}$ starting at $1200 \mathrm{UTC}$ on 5 August 2006 (courtesy of http://aoc.amma-international.org).

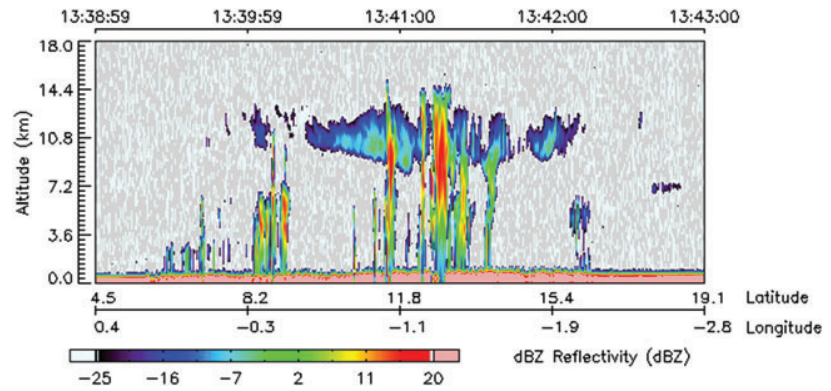

Figure 3. Vertical southeast-northwest oriented cross-section of attenuating W-band radar reflectivity from a CloudSat satellite overpass crossing northwestward over the MCS cloud band at 1341 UTC 6 August 2006. effect on both long-wave and short-wave radiation has been accounted for.

\subsubsection{Land information system (LIS)}

LIS is a high-resolution land modelling and data assimilation system that integrates the use of advanced land surface models, high-resolution satellite and observational data, data assimilation techniques, and high-performance computing tools (Kumar et al., 2006). LIS has been coupled to the ARW core, enabling (i) a coupled system to study land-atmosphere interactions, and (ii) an uncoupled system to prepare initial conditions by multi-year 'spin-up' integrations and data assimilation techniques (Kumar et al., 2007). However, as the land surface impacts were not the 
(a)

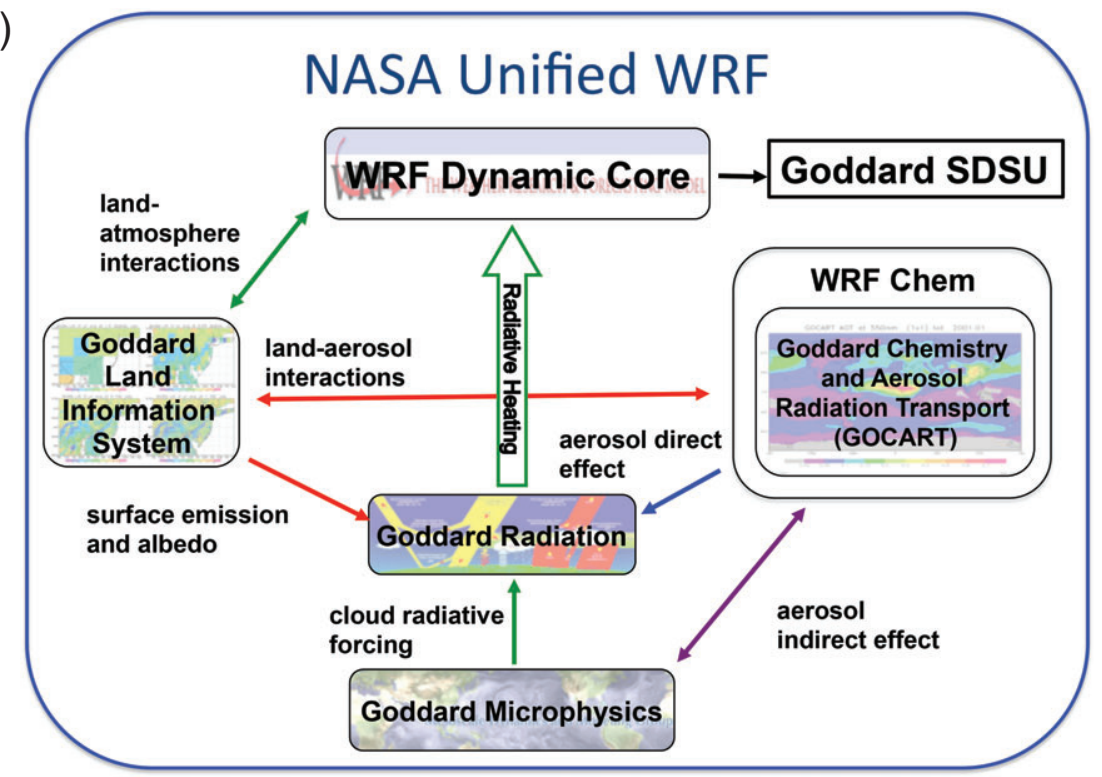

(b)

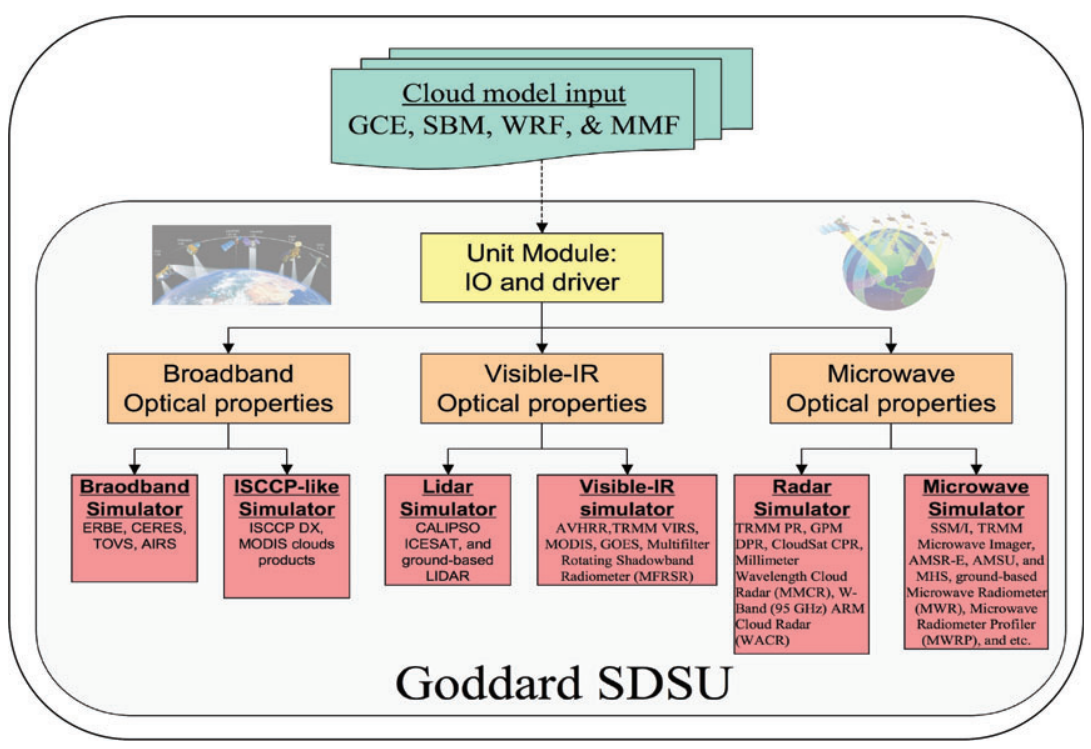

Figure 4. (a) Physics packages included in the NASA Unified WRF and (b) Goddard Satellite Data Simulator Unit.

goal of the current study, the land surface data provided by the ERA-Interim reanalysis data (Dee et al., 2011) were adopted in the numerical simulations directly and LIS was not utilized in this study.

\subsubsection{Satellite data simulator unit}

The Goddard Satellite Data Simulator Unit (G-SDSU) is an end-to-end multi-satellite simulator unit (Figure 4(b)). It has six simulators at present: passive microwave, radar, visible-infrared spectrum, lidar, ISCCP (International Satellite Cloud Climatology Project) and broadband. The SDSU can compute satellite-consistent radiances or backscattering signals from simulated atmospheric profiles and condensates consistent with the Goddard microphysics. For example, it can generate estimates of retrieved microphysical quantities that can be directly compared with high-resolution satellite (i.e. TRMM and CloudSat) products. These simulated radiances and backscattering can be directly compared with satellite observations, establishing a satellite-based framework for evaluating the cloud parametrizations. This method is superior to the traditional method of validating models with satellite-based products, since models and satellite products often use different assumptions in their cloud microphysics (Matsui et al., 2009; Masunaga et al., 2011).

\subsection{GOCART in WRF-Chem}

WRF-Chem is WRF coupled with chemistry; however, the name is often used to refer to just the chemistry part (including this study) because the chemistry portion must be run inside WRF and cannot be run independently. The model simulates the emission, transport, mixing, and chemical transformation of trace gases and aerosols simultaneously with the meteorology. The model is used to investigate regional-scale air quality, field programme analysis, and cloud-scale interactions between clouds and chemistry. The development of WRF-Chem is a collaborative effort among many research communities. The WRF-Chem model is released as part of the WRF modelling package and follows the same software structure as WRF. Details about WRF-Chem can be found at 'http://ruc.noaa.gov/wrf/WG11/'. In this study, only the GOCART portion of WRF-Chem was used, with all other chemistry modules turned off to speed up computation. The GOCART portion of WRF-Chem simulates major aerosol types, namely sulphate, dust, black carbon (BC), organic carbon (OC), and sea salt as well as precursor gas species (Chin et al., 2000, 2009). GOCART results have been extensively evaluated with observations from field campaigns, ground-based networks, and satellites (e.g. Chin et al., 2004, 2007; Ginoux et al., 2004; Kinne et al., 2006; Yu et al., 2008), and have been widely used by many research groups and operational centres. The atmospheric sulphur cycle is simulated including 
gas species of $\mathrm{SO}_{2}$ (emitted from anthropogenic, volcanic, and biomass burning sources), dimethylsulphide (DMS, emitted from ocean) and aerosol species of sulphate (formed from oxidation of gas species) and methanesulphonate (MSA, formed from DMS oxidation). Besides sulphate, other major aerosol types included in the model are dust (five different particle sizes), BC, OC, and sea salt (four different particle sizes). The model takes into account the atmospheric processes of chemistry, convection, advection, boundary-layer mixing, dry and wet deposition, and gravitational settling. Aerosol particle sizes from 0.01 to $10 \mu \mathrm{m}$ are simulated with parametrized hygroscopic growth, which is a function of ambient relative humidity.

\section{Aerosol-cloud-microphysics-radiation coupling}

In general, aerosol effects on microphysics can be included in higher-order microphysics, such as two-moment or spectra-bin microphysics, through the production of cloud condensation nuclei (CCN) and ice nuclei (IN). This means that the number of 3-D microphysical prognostic parameters will be increased substantially. Therefore, when aerosol impacts are included in the microphysics of a CRM, it increases the computational burden. One goal of this study is to incorporate aerosol impacts into the Goddard one-moment microphysics scheme to account for the first-order effects, namely varying the drop number concentrations and the cloud-to-rain and ice-to-snow conversion rates, without substantially increasing the computational burden. When WRF-Chem/GOCART is activated and aerosol species are predicted every time step, the computing time roughly doubles, and the model output increases substantially.

In NU-WRF, the Goddard microphysics and radiation schemes have been coupled with the aerosol fields forecast by GOCART in WRF-Chem to account for the aerosol direct (radiation) and indirect (cloud microphysics) effects. In the current coupling, all atmospheric parameters including aerosols and cloud hydrometeors are explicitly predicted on the same highresolution grid at every time step. Both CCN and IN are diagnostic parameters calculated from the WRF-Chem/GOCART-predicted aerosol mass concentrations in the Goddard one-moment microphysics scheme and are not advected by WRF's dynamic core. Wet deposition is handled within the GOCART/WRFChem module with a simplified parametrization using the model forecast precipitation. It is not handled explicitly by the cloud microphysics. Inside the Goddard microphysics scheme, for a given air temperature and supersaturation, $\mathrm{CCN}$ is calculated from the 14 aerosol species predicted by GOCART based on the Koehler curve (Koehler et al., 2006; Andreae and Rosenfeld, 2008), while the concentration of ice nuclei (IN) is obtained following the approach of Demott et al.(2010), which is

$$
N_{i}=a T^{b} n_{\mathrm{aer}>0.5^{(c T+d)}}
$$

where $T=273.16-T_{\mathrm{k}}, a=0.0000594, b=3.33, c=0.0264$, and $d=0.0033 . T_{\mathrm{k}}$ is cloud temperature in degrees Kelvin. $N_{i}$ is IN number concentration (number/L). The term $n_{\text {aer }>0.5}$ is the number concentration of aerosol particles with diameters larger than $0.5 \mu \mathrm{m}$. The cloud (ice crystal) number concentration is assumed to equal the CCN (IN) concentration. For those grids without a significant level of supersaturation, minimum numbers of cloud and ice crystals are used. The diagnostic cloud number concentration affects the cloud-to-rain auto-conversion rate based on Liu and Daum (2004). The diagnostic ice crystal number concentration affects both the Bergeron process (ice crystal-to-snow conversion rate) and the growth of cloud liquid water to cloud ice due to deposition based on Lang et al.(2011). Overall, having more atmospheric aerosols tends to suppress warm rain processes, increase supercooled water, increase ice crystals, suppress conversion to snow and thereby invigorate convection in a particular environment. In the Goddard LW and SW radiation schemes, all 14 GOCART aerosol species are used to calculate the aerosol optical thickness, single-scattering albedo and asymmetry factor to estimate dust-induced radiative heating (Chou and Suarez, 1999, 2001). The aerosol size distributions are log-normal. The Goddard radiation schemes also account for the single-scattering properties of snow, graupel and rain.

\section{Model set-up and simulation design}

For the coupled GOCART simulations, double-nested domains were used with a horizontal grid spacing of 18,6 and $2 \mathrm{~km}$ and corresponding grids of $391 \times 271,424 \times 421$ and $466 \times 466$ points for the outer, middle and inner domains, respectively (Figure 5). The outer domain (D1 in Figure 5), which extends from the eastern Atlantic Ocean near the African coast to the Red Sea/Ethiopia and from northern Algeria to the central Congo, is large enough to contain most of the northern half of the African continent and most of the Sahara Desert while the inner domain (D3 in Figure 5) is large enough to cover the entire MCS passing through Niamey at relatively high horizontal resolution $(2 \mathrm{~km})$. A terrain-following vertical coordinate with 61 layers was constructed with resolutions of $5-10 \mathrm{hPa}$ inside the planetary boundary layer (PBL) and $20-25 \mathrm{hPa}$ above the PBL. Time steps of 36,12 and $4 \mathrm{~s}$ were used in the outer and two nested grids, respectively.

The Grell-Devenyi ensemble cumulus parametrization scheme (Grell and Dévényi, 2002) was used for the coarse outer domain. The cumulus parametrization scheme was turned off in the middle and inner domains while the Goddard cloud microphysics scheme was used in all three domains. The Goddard radiation scheme was used to provide LW and SW heating that interact with the atmosphere dynamic core. The PBL parametrization for this study was the Mellor-Yamada-Janjic (Mellor and Yamada, 1982; coded and modified by Dr Janjic for the NCEP Eta Model) level-2 turbulence closure model for the full range of atmospheric turbulent regimes. The surface heat and moisture fluxes (from both ocean and land) were computed from similarity theory (Monin and Obukhov, 1954). The 'Noah' (from NCEP-Oregon State University-US Air Force-National Weather Service Office of Hydrologic Development) land surface model was used, which is based on Chen and Dudhia (2001). It is a four-layer soil temperature and moisture model with canopy moisture and snow cover prediction. It provides sensible and latent heat fluxes to the boundary-layer scheme. The soil temperature and moisture were also initialized from the ERA-Interim global reanalysis data.

In this study, NU-WRF was initialized from ERA-Interim global reanalysis data (Dee et al., 2011). ERA-Interim reanalysis data has a T255 horizontal resolution $\left(\sim 0.7^{\circ}\right)$ with 37 vertical levels. Time-varying lateral boundary conditions, also from the same reanalysis data, were provided at $6 \mathrm{~h}$ intervals. The model was integrated for $48 \mathrm{~h}$, from 0000 UTC 5 August to 0000 UTC 7 August 2006. For GOCART, the global GOCART simulation

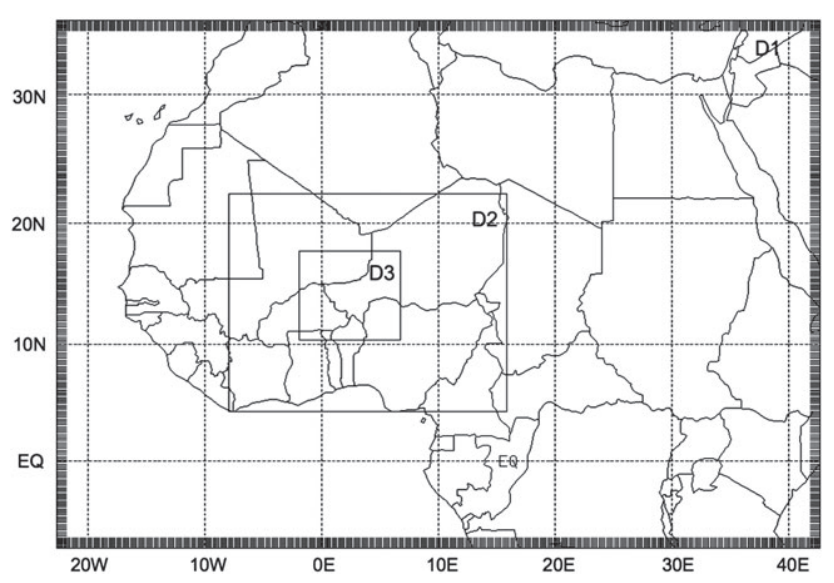

Figure 5. Double-nested domains with horizontal grid spacing of 18, 6 and $2 \mathrm{~km}$ constructed for this study. 

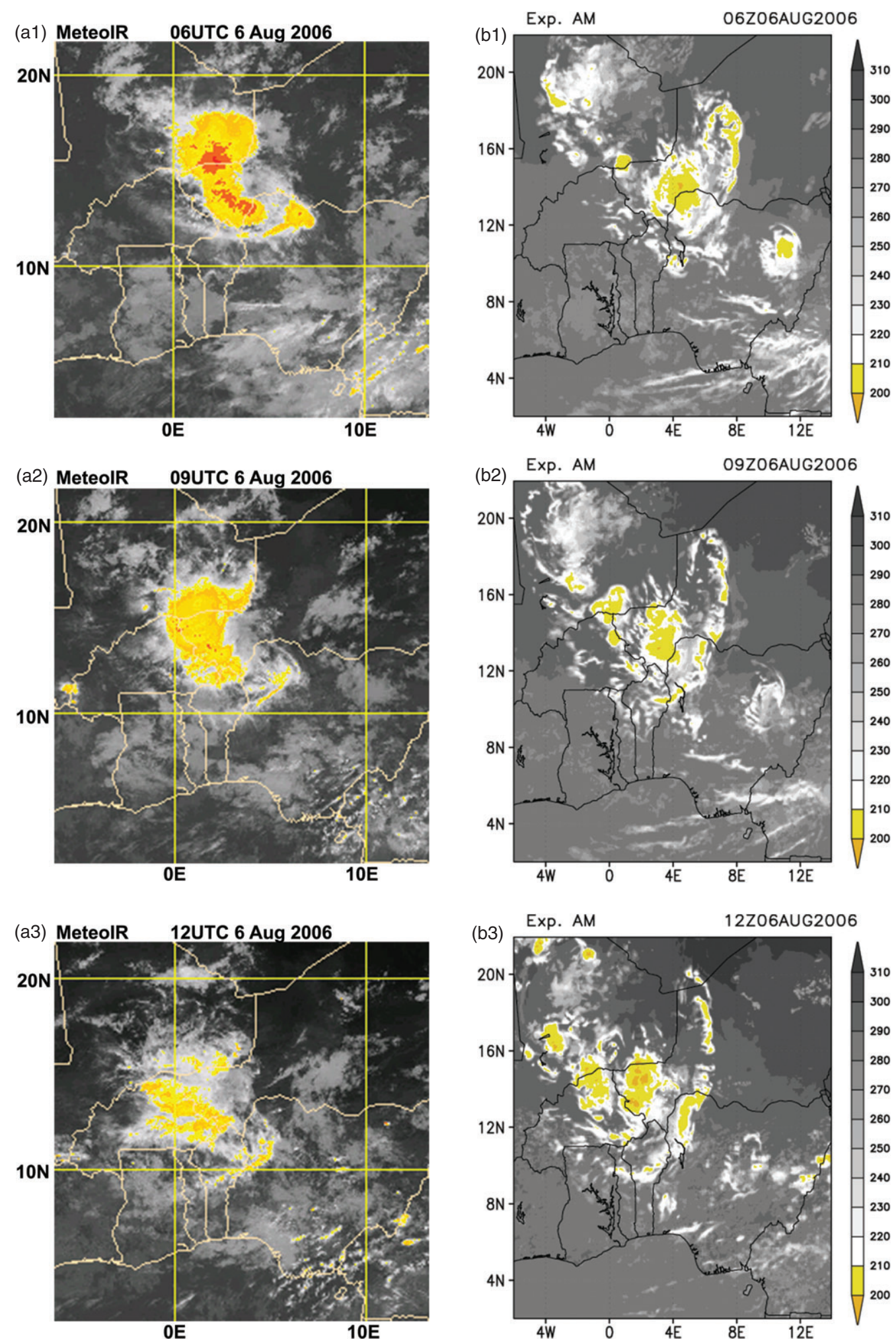

Figure 6. (a) Meteosat and (b) WRF-simulated IR Tbs at (1) 0600 UTC, (2) 0900 UTC and (3) 1200 UTC on 6 August 2006. The WRF-simulated results are from Exp. AM. Meteosat IR Tbs are the same as those in Figure 2.

driven by the Goddard Earth Observing System Data Assimilation System (GEOS DAS with output saved every $3 \mathrm{~h}$ ) was used for the initial and time-varying lateral boundary conditions (Chin et al., 2009). In this simulation, the oxidant fields from a global chemistry transport model, part of the NASA Global Modeling Initiative (GMI: Rotman et al., 2001) were used to simulate the chemical processes related to aerosol formation. The coupled NU-WRF GOCART simulations were also driven by both anthropogenic and natural emissions, which were obtained from the emission database compiled for the global GOCART simulation (Chin et al., 2009). The anthropogenic emissions of $\mathrm{SO}_{2}, \mathrm{BC}$ and $\mathrm{OC}$ are from Streets et al. $(2004,2009)$ and Bond et al.(2004). Biomass burning emissions of $\mathrm{SO}_{2}, \mathrm{BC}$ and OC are from the Global Fire Emission Database version 3 (GFED v3: Mu et al., 2011). Dust and sea salt emissions are calculated in the model using instantaneous surface winds, a predefined dust source map, and other surface conditions (Ginoux et al., 2001; Chin et al., 2003). DMS is a natural precursor of sulphate aerosols. Its emission flux is based on a climatology distribution (Lana et al., 2011) and adjusted by the instantaneous sea surface temperature (SST). In order to study both direct (radiation) and indirect (cloud microphysics) aerosol effects, four different NU-WRF simulations (Table 1) were conducted with: (i) aerosol effects included in the cloud microphysics but not radiation 
Table 1. Aerosol effects included in each experiment.

\begin{tabular}{lcccc}
\hline Experiment & AM & AR & AMR & Clean \\
\hline Aerosol indirect (microphysics) effect & $\checkmark$ & & $\checkmark$ \\
Aerosol direct (radiation) effect & & $\checkmark$ & $\checkmark$ & \\
\hline
\end{tabular}

(Exp. AM, designated as the control experiment); (ii) full aerosol effects in radiation but minimal in the cloud microphysics with aerosol values set to the absolute minimum values in the atmosphere (i.e. a clean environment, Exp. AR); (iii) full aerosol effects for both microphysics and radiation (Exp. AMR); and (iv) no aerosol effects on radiation and minimal (i.e. a clean environment) on the microphysics (Exp. Clean).

(a1)

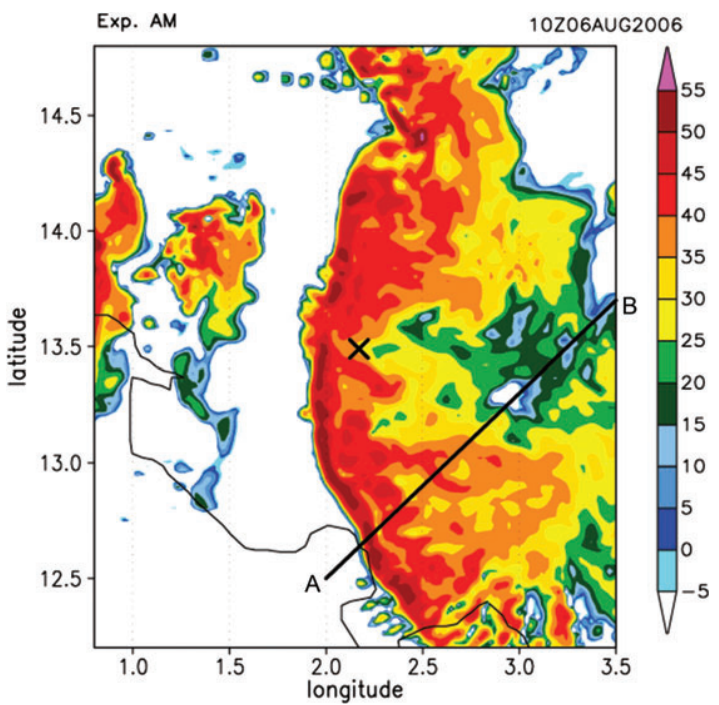

(a2)

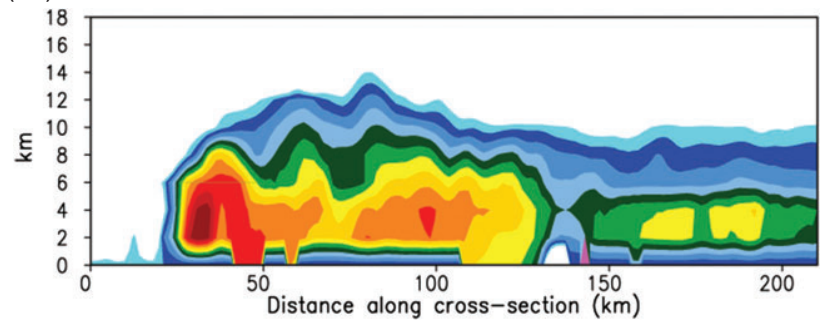

\section{Simulation results}

6.1. IR brightness temperature, radar reflectivity and rainfall comparisons

Because the range of the MIT radar at Niamey was only $150 \mathrm{~km}$, it is difficult to compare the model-simulated MCS, which stretches for almost $1000 \mathrm{~km}$, with just the radar reflectivity data collected from Niamey. In order to obtain a more comprehensive comparison, IR Tbs from Exp. AM (i.e. the control experiment) were computed from the G-SDSU and then compared directly to the observed IR images (Figure 6). Overall, both the modelled and observed IR images show a well-organized MCS passing through Niamey on the morning of 6 August; however, the

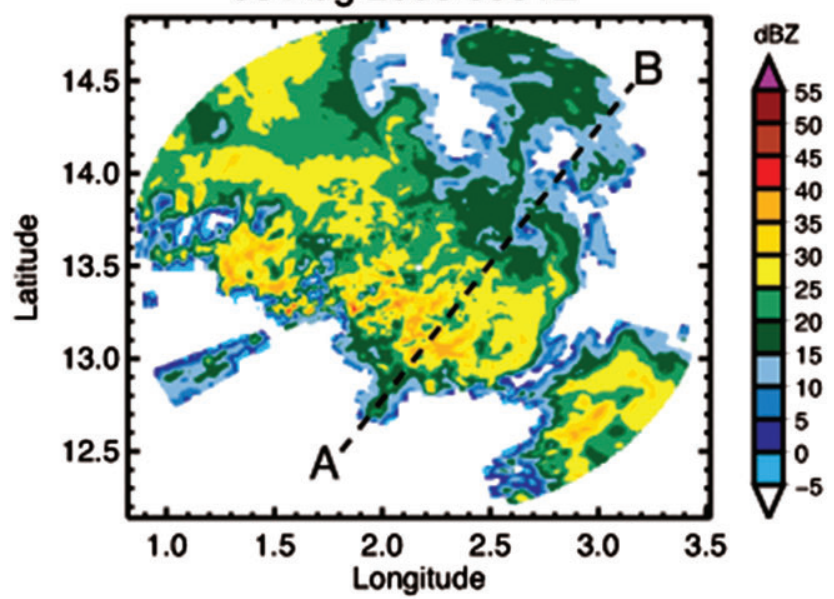

(b2)

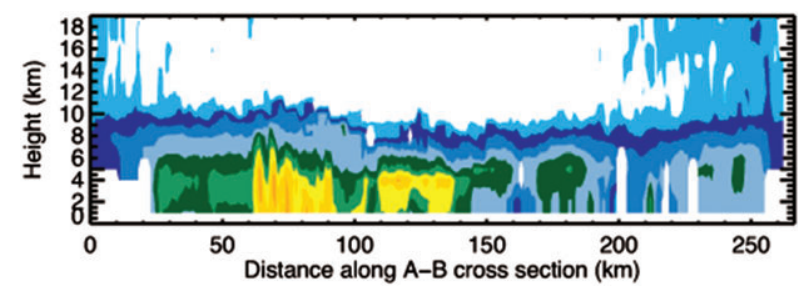

Figure 7. (a1) WRF-predicted and (b1) the MIT-observed reflectivities at $1 \mathrm{~km}$ at 1000 UTC on 6 August 2006. The lines in (a1) and (b1) indicate the reflectivity cross-section in (a2) and (b2), respectively. 'X' in (a1) denotes the location of the MIT radar at Niamey, Niger.
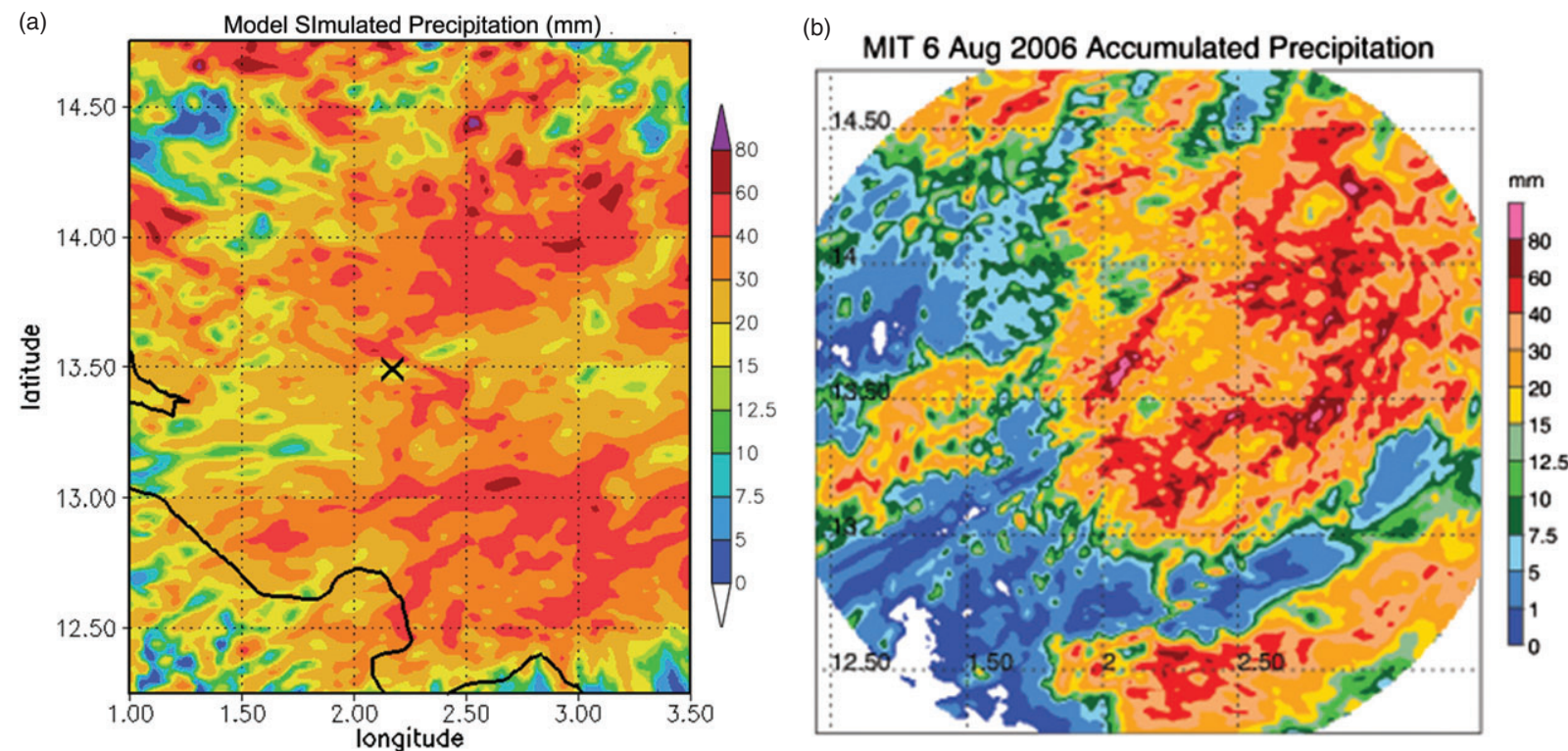

Figure 8. 24 h-accumulated precipitation (mm) from (a) Exp. AM and (b) estimated from the MIT radar for 6 August 2006. The ' $X$ ' in (a) indicates the location of the MIT radar at Niamey. 


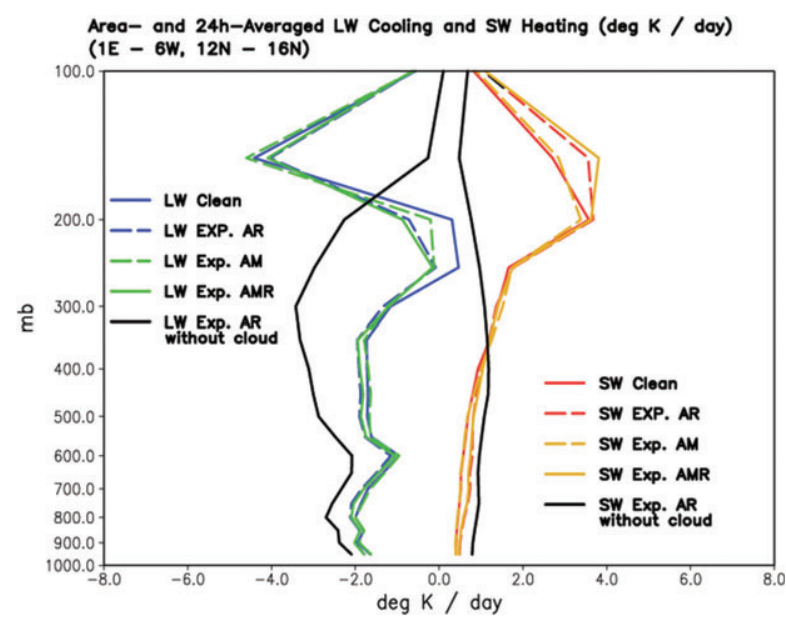

Figure 9. Area- and 24 h-averaged LW cooling and SW heating rate $\left(\mathrm{K} \mathrm{day}^{-1}\right)$ profiles for the area $1^{\circ} \mathrm{E}$ to $6^{\circ} \mathrm{W}$ and $12^{\circ} \mathrm{N}$ to $16^{\circ} \mathrm{N}$, for 6 August 2006 .

observed images show a longer north-south extension while the simulated MCS has an elongated north-south cloud line behind the main cloud band. As seen in the observed IR images (Figures 2 and 6), the observed MCS reached its strongest intensity on the morning of 6 August 2006, as it was passing through Niamey. After the convective cloud band passed Niamey at around 0900 UTC 6 August, it started decaying and also became more northwest-southeast oriented as the southern half of the band moved slower than the northern half. On the other hand, the model-simulated MCS from Exp. AM reached its strongest intensity in the late morning when it was over Niamey, which indicates the MCS moved slower in the model. The simulated system also became more northwest-southeast oriented in the late morning of 6 August as convection further developed in the northern part of the overall band. Overall, the track of the simulated MCS was similar to that observed in the IR Tb images, except that the observed system passed through the region a few hours earlier than the simulated one.

In Figure 7, the predicted reflectivity (only results from Exp. AM are shown as all four experiments produced similar structures) is compared with the observed reflectivity collected with the MIT C-band radar at Niamey $\left(13.49^{\circ} \mathrm{N}, 2.17^{\circ} \mathrm{E}\right)$ during the AMMA SOP (Guy et al., 2013). The model produces a linear system as observed; however, reflectivities in the leading edge of the second (larger) cloud band are stronger than observations, and the orientation is more north-south as compared to the observed northwest-southeast. This is probably due to the fact that the observed MCS had started to decay by this time. The general morphology and structure is comparable though, with distinct clusters of convection along the line and the occurrence of secondary (decaying) convection behind the initial line.

Both predicted and observed echo tops reach to around $12 \mathrm{~km}$ in the convective region and around $10 \mathrm{~km}$ in the trailing stratiform region (Figure 7). However, the predicted reflectivities are more intense (note the areas $>40 \mathrm{dBZ}$, shown in red) and the leading edge more sharply defined in the simulations. Both the model-predicted and observed reflectivity patterns show two strong convective areas in the leading part of the cloud band and a long trailing stratiform region as indicated in both lower plots of Figure 7. Due to the $150 \mathrm{~km}$ range of the MIT radar, the full extent of the trailing anvil region was not captured. The predicted IR Tbs and radar reflectivities as well as the 24 h-accumulated precipitation from the other experiments have a similar pattern and for conciseness are not shown here.
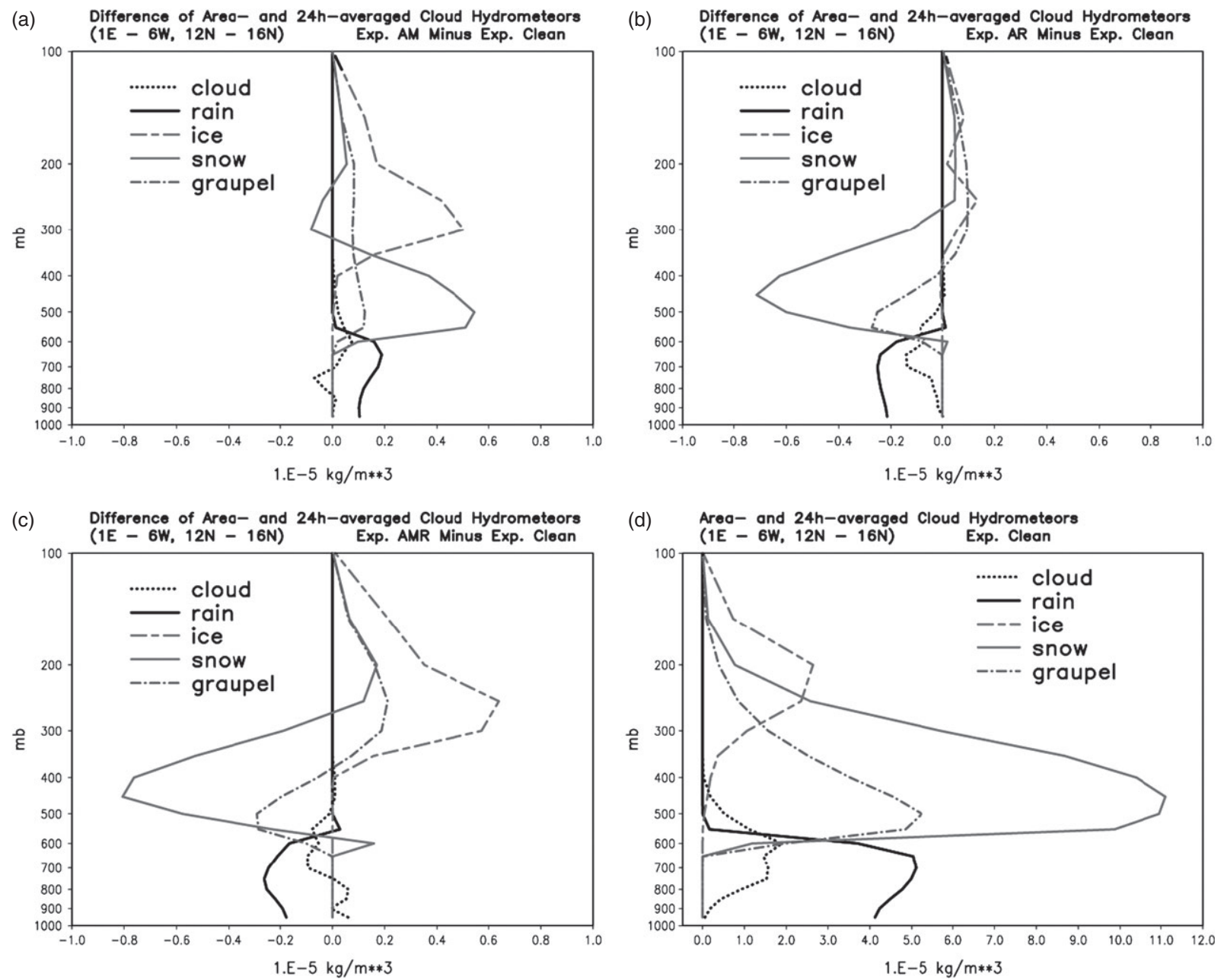

Figure 10. Area- and 24 h-averaged difference of cloud hydrometeor profiles between (a) Exp. AM, (b) Exp. AR, (c) Exp. AMR and Exp. Clean. (d) Area- and $24 \mathrm{~h}$-averaged cloud hydrometeor profiles of Exp. Clean. The area and $24 \mathrm{~h}$ period are the same as in Figure 9. 
(a)

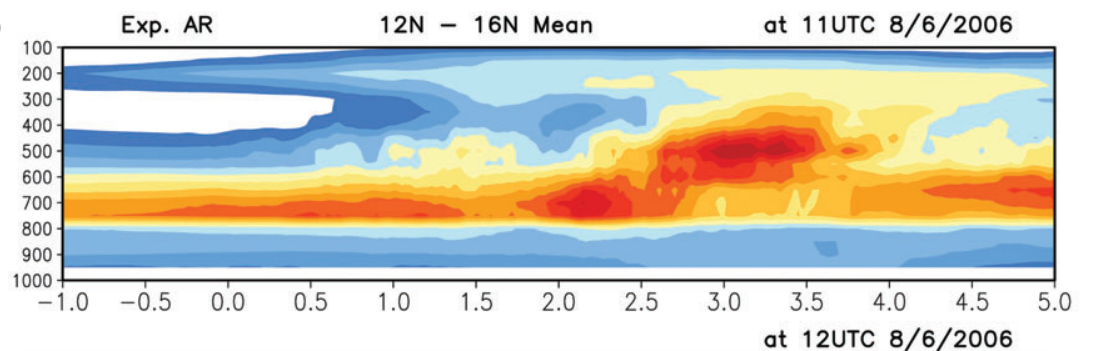

at 11 UTC $8 / 6 / 2006$
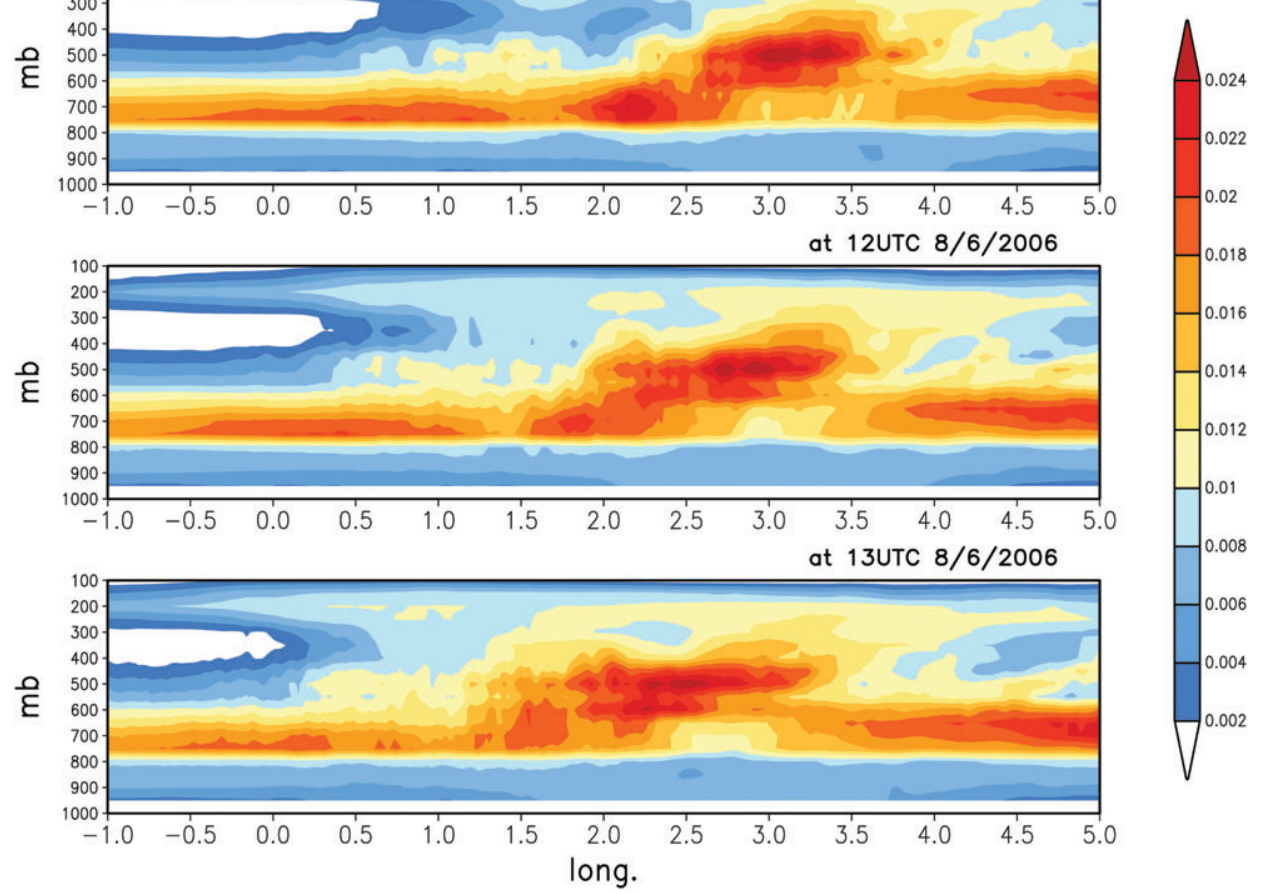

(b)
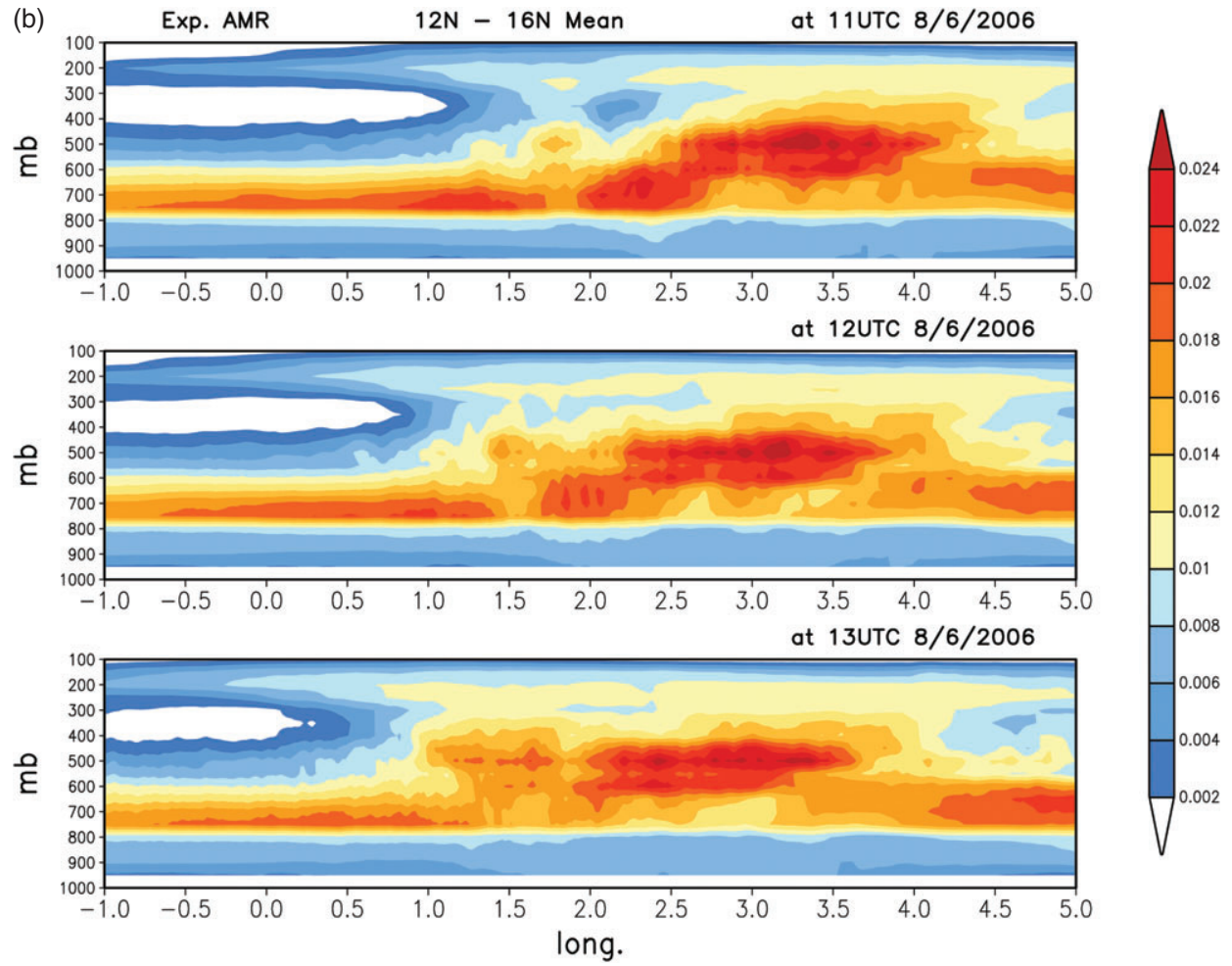

Figure 11. Model-predicted mean aerosol optical depth (AOD) cross-sections between $12^{\circ} \mathrm{N}$ and $16^{\circ} \mathrm{N}$ at 1100, 1200 and 1300 UTC on 6 August 2006 from (a) Exp. $\mathrm{AR}$ and (b) Exp. AMR. The AOD value represents the integrated AOD value in each layer.

Rainfall comparisons are rather difficult as there is no reliable rain-gauge network in the area. Therefore, the $24 \mathrm{~h}$-accumulated precipitation derived from the MIT radar data at Niamey was adopted to provide a quantitative comparison with the model rainfall forecast. Following Guy et al.(2013), reflectivities from the MIT radar were converted to rain rates $\left(\mathrm{mm} \mathrm{h}^{-1}\right)$ via a $Z-R$ (reflectivity-rain) relationship. The rain values were then summed throughout the period of interest at each grid point. To find the area-mean accumulation, the total accumulated rain was divided by the area of the scan domain. Although there may be some uncertainties regarding the MIT radar estimates, it is the best estimate available for the observed rainfall in this area in the absence of a dense rain-gauge network. Details on the uncertainties in the precipitation estimates from the MIT radar can be found in Russell et al.(2010). The dashed circle with a $150 \mathrm{~km}$ radius in Figure 8 is the same region covered by the MIT radar in Niamey. As seen in Figure 8, both the model predictions and the MIT radar estimates show comparable precipitation amounts and two distinct bands of heavier rainfall (one north and one south of Niamey) inside the $150 \mathrm{~km}$ circle covered by the MIT radar. However, the model seems to have overpredicted the amount of rain in the southern band and also the area west of Niamey. Table 2 confirms the overprediction of rainfall by all four experiments. For comparison, rainfall estimates from TRMM were also used. Overall, Exp. Clean produced the best average rainfall forecast when compared to the rainfall estimates from 
Table 2. (a) Domain-averaged $24 \mathrm{~h}$-accumulated rainfall ( $\mathrm{mm})$ from the model experiments and TRMM and (b) area-mean simulated and observed $24 \mathrm{~h}$ accumulated rainfall inside the area covered by the MIT radar at Niamey.

\begin{tabular}{lcccc}
\hline $\begin{array}{l}\text { (a) } \\
\text { Clean }\end{array}$ & AM & AR & AMR & TRMM \\
\hline $\begin{array}{l}11.17 \\
\text { (b) }\end{array}$ & 11.23 & 11.51 & 11.18 & 9.12 \\
Clean & AM & AR & AMR & MIT Radar \\
\hline 28.24 & 26.53 & 27.90 & 27.39 & 20.80 \\
\hline
\end{tabular}

TRMM, while Exp. AM produced the best forecast as compared to the MIT radar at Niamey. Due to the coarse resolution $\left(0.25^{\circ}\right)$ of the TRMM rainfall retrievals, which cover a much larger area than the MIT radar, the model forecast rainfall output from the entire middle domain (6 $\mathrm{km}$ resolution) was used to compare against the TRMM rainfall (Table 2a). A large portion of the area in the middle domain had little or no rain. This may be why the results from Exp. Clean were slightly better as compared to the TRMM rainfall retrievals. On the other hand, the comparison with the MIT radar was only for the area through which the MCS passed and was inside the radar range. Both the MIT radar and model output showed a lot of rainfall at most of the points inside the area. Table 2 shows that the comparisons could vary in different directions when different regions and different observed rainfall retrievals are used. Nevertheless, the aerosol indirect effect on microphysics reduced the amount of the area-averaged rainfall in Exps AM and AMR as compared to those in Exps Clean and AR even though the differences are rather small due to the fact that they were all mean values.

\subsection{Impact of aerosol direct (radiation) and indirect (micro- physics) effects}

Due to the aerosol absorption of LW and SW radiation, aerosols can warm the atmosphere. Figure 9 shows the areaand $24 \mathrm{~h}$-average heating rate due to LW and SW radiation within the area $1^{\circ} \mathrm{E}$ to $6^{\circ} \mathrm{W}$ and $12^{\circ} \mathrm{N}$ to $16^{\circ} \mathrm{N}$ through which the MCS passed. The $24 \mathrm{~h}$-average heating rate was calculated from 0000 UTC 6 August to 0000 UTC 7 August, when the simulated MCSs passed through the area. In the model, the strongest SW heating exists in the layer between 250 and $150 \mathrm{hPa}$, indicating the strong absorption of SW radiation by cirrus clouds in the upper troposphere. The aerosol direct effect (mainly due to mineral dust) also had the biggest impact in the layer just above $200 \mathrm{hPa}$ near the cloud tops, roughly increasing the SW heating by about $0.8 \mathrm{~K} \mathrm{day}^{-1}$ at $150 \mathrm{hPa}$ (dashed red and solid orange lines in Figure 9). This is consistent with the increase in cloud ice and other solid ice particles due to aerosols (Figure 10) above $300 \mathrm{hPa}$ Exp. AMR has the largest SW heating in the upper troposphere, slightly larger than Exp. AR, while Exp. AM shows only a minimal impact. This result agrees with the elevated heat pump hypothesis described in Lau and Kim (2006). The aerosol direct effect also increased the SW heating slightly in the layer between 800 and $600 \mathrm{hPa}$, the level of the SAL, where the highest simulated dust concentrations were (Figure 11). There was virtually no impact due to the aerosol indirect effect (microphysics) as evidenced by the nearly identical SW profiles for the clean (solid red) and Exp. AM (dash orange lines) simulations (Figure 9). The strongest LW cooling occurred at around $150 \mathrm{hPa}$, near and above the cloud tops. The experiments without the direct effect (Exps Clean and AM) show a slightly larger peak cooling (by $-0.3 \mathrm{~K} \mathrm{day}^{-1}$ ) than those with the direct effect (Exps AR and AMR). Elsewhere in the rest of the column below the cloud tops (i.e. inside and below the cloud), the experiments with the direct effect (Exps AR and AMR) produced slightly stronger LW cooling than those without (Exps Clean and AM). The weakest LW cooling occurred in the layer between 250 and $200 \mathrm{hPa}$, just below where the strongest SW heating occurred; the experiments with the aerosol

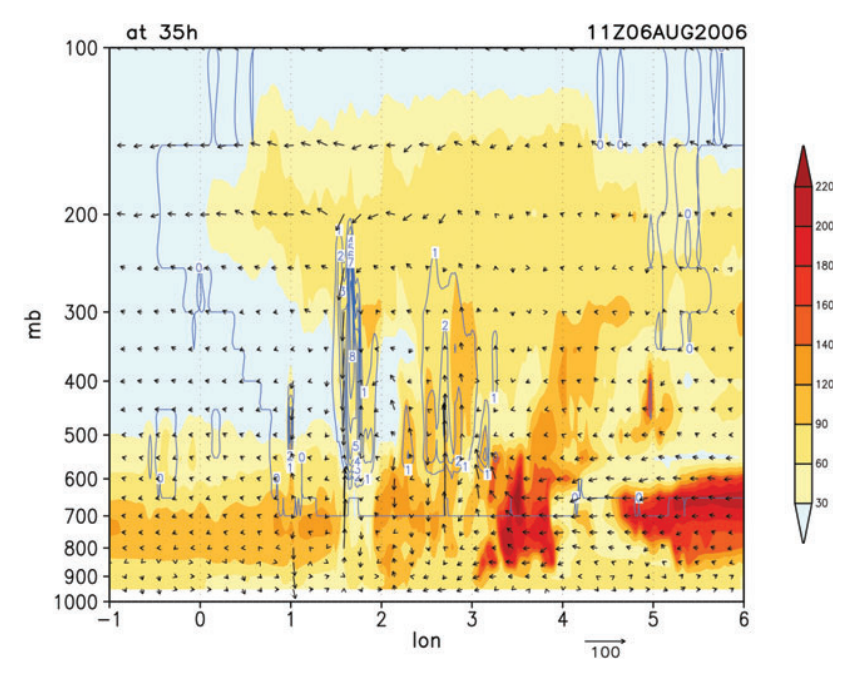

Figure 12. Cross-section of model-predicted dust concentration $(\mu \mathrm{g} / \mathrm{kg}$ of dry air, shaded area), total ice (ice+graupel+snow, $\mathrm{g} \mathrm{kg}^{-1}$, contours), and wind vectors along $13.75^{\circ} \mathrm{N}$ from Exp. AMR at 1100 UTC 6 August 2006.

direct effect (Exps AR and AMR) produced more cooling in this layer than those without (Exps AM and Clean). A secondary minimum in the LW cooling profiles occurred at around 600 $\mathrm{hPa}$ just above the maximum aerosol/dust concentration in the lower troposphere. However, it is not clear why the direct effect induced by the presence of aerosols/dust resulted in more LW cooling below the cloud tops. One possible explanation is that the aerosols/dust altered the cloud structure and thereby the LW cooling. In a separate model experiment, the effect of clouds was removed in the radiation calculation (black lines in Figure 9). As a result, LW radiative cooling dramatically increased below and decreased near and above cloud tops. The cloud impact on LW and SW radiation was almost an order of magnitude higher than the aerosol impact.

Average vertical profiles for all cloud hydrometeors (Figure 10), both liquid (cloud and rain) and ice (ice, snow and graupel), were also calculated for the same domain and time period as in Figure 9. The difference between cloud droplets and raindrops is the size of the particles. In the Goddard microphysics scheme, cloud droplets are small liquid particles and are assumed to have virtually no fall speed. All of the experiments result in similar mean hydrometeor profiles as the one from Exp. Clean (Figure 10(d)) with a moderate amount of ice between 150 and $300 \mathrm{hPa}$, a moderate amount of graupel and large amount of snow between 300 and $600 \mathrm{hPa}$, and a moderate amount of rain below $600 \mathrm{hPa}$. A closer analysis reveals that the aerosol indirect (microphysics) effect (Exp. AM, Figure 10(a)) generally resulted in increased amounts of all hydrometeors except for a minor reduction in the amount of snow between 250 and $300 \mathrm{hPa}$ and cloud between 700 and $900 \mathrm{hPa}$. The aerosol direct effect (Exp. AR, Figure 10(b)) led to a slight decrease in warn rain below the melting level $(\sim 600 \mathrm{hPa})$ and graupel between 400 and $600 \mathrm{hPa}$, a large decrease in snow between 250 and $600 \mathrm{hPa}$, and slight increases in snow above $250 \mathrm{hPa}$ and ice and graupel above 400 $\mathrm{hPa}$. When both the aerosol direct and indirect effects were taken into account (Exp. AMR, Figure 10(c)), there was a decrease in the amount of warn rain below the melting level $(\sim 600 \mathrm{hPa})$ and graupel between 400 and $600 \mathrm{hPa}$ and a decrease in snow between 250 and $600 \mathrm{hPa}$ similar to the results from Exp. AR. However, in Exp. AMR there is a much larger increase in ice and graupel above the melting level and snow above $250 \mathrm{hPa}$ compared to Exp. AR, due to the inclusion of the indirect effect on microphysics.

Overall, when both direct and indirect aerosol effects are taken into account (Exp. AMR), mid- and low-level cloud decrease but high (cirrus) cloud increases slightly more than for the indirect effect alone (Exp. AM). When only the aerosol direct effect is activated (Exp. AR), there is a slight increase in high cloud but 

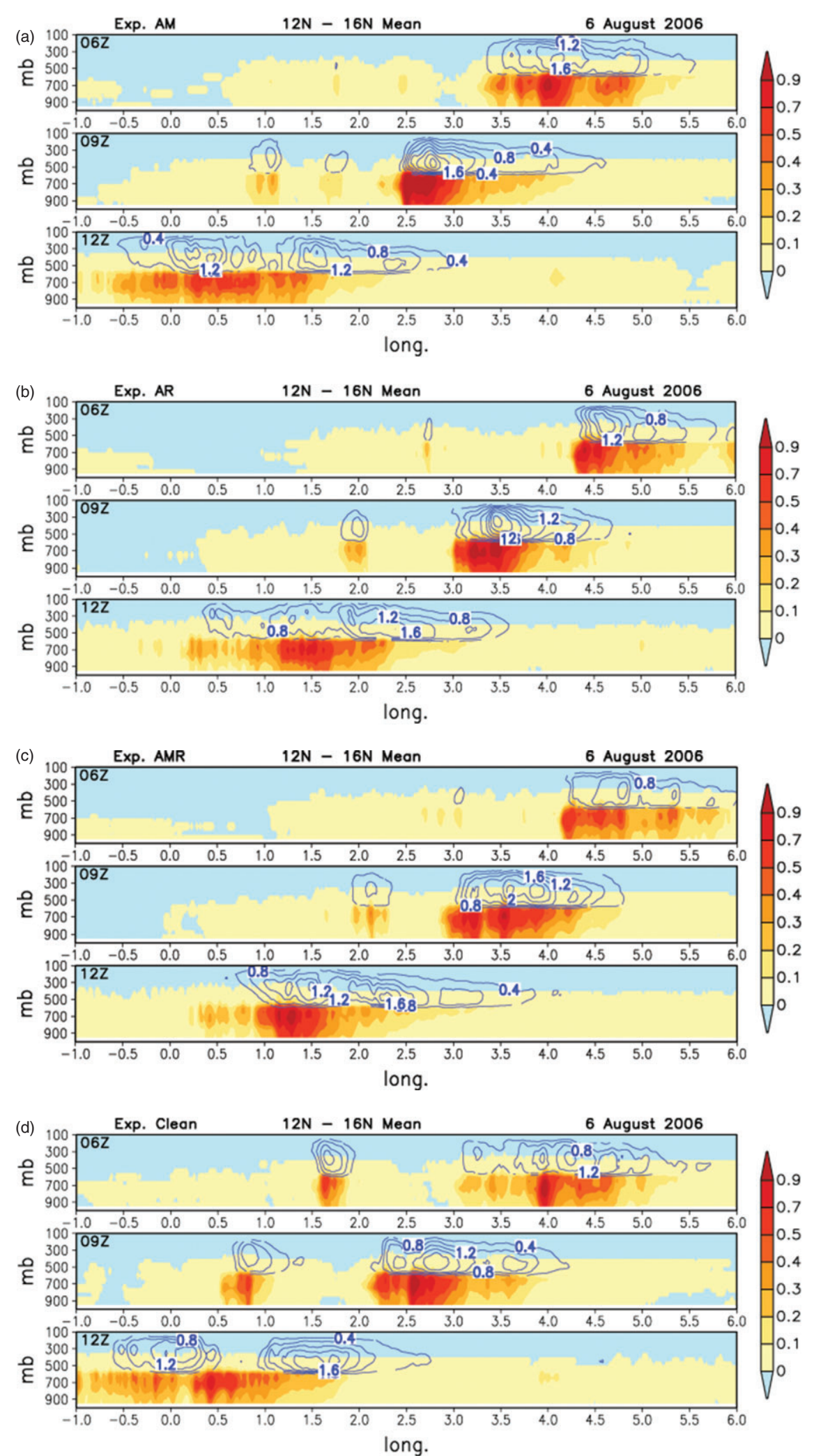

Figure 13. Model-predicted mean cloud hydrometeor cross-sections between $12^{\circ} \mathrm{N}$ and $16^{\circ} \mathrm{N}$ at 0600,0900 and 1200 UTC on 6 August 2006 from (a) Exp. AM, (b) Exp. AR, (c) Exp. AMR and (d) Exp. Clean with the shaded area representing liquid (cloud+rain, $\mathrm{g} \mathrm{kg}^{-1}$ ) and the contours representing ice (ice+snow+graupel, $\mathrm{g} \mathrm{kg}^{-1}$ ) water content.

decrease in middle and low cloud. The results from Exp. AM show that when only the aerosol indirect effect is included in the model, more cloud (especially high and middle) stays in the atmosphere, resulting in less precipitation reaching the ground (as seen in Table 2 for Exp. AM). This agrees well with previous studies (Khain et al., 2009; Tao et al., 2012). The combined results from Exps AM, AR and AMR suggest that: (i) higher aerosol/dust concentrations result in more CCN and IN, increasing the amount of all non-raining hydrometeors because of the indirect effect on cloud microphysics; and (ii) the direct effect on radiation acts to reduce the amount of precipitating particles (rain, snow and graupel in the middle and lower cloud) and increase the amount of solid ice particles in the high (cirrus) cloud. These results also show increased amounts of ice particles (cloud ice) with increasing aerosol/dust concentrations (i.e. more IN) due to strong convection.

To further examine the aerosol/dust effects on the cloud system, cross-sections were constructed (Figure 11) of the modelpredicted mean aerosol optical depth (AOD, per vertical layer depth). The cross-sections were taken between $12^{\circ} \mathrm{N}$ and $16^{\circ} \mathrm{N}$ 
(a)
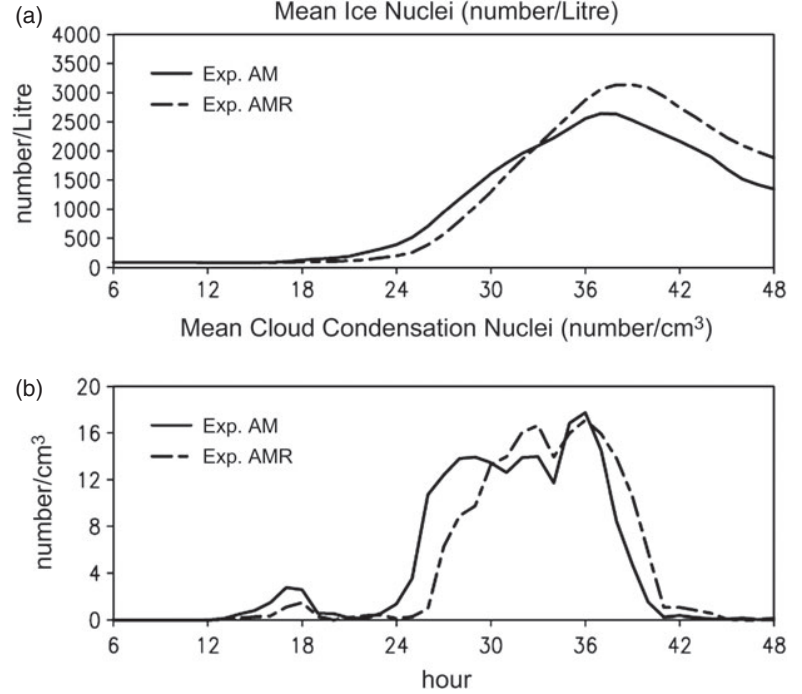

Figure 14. Time series of area-mean (a) IN and (b) CCN from Exp. AM and Exp. AMR. The area mean is for the same area as in Figure 9.

at 1100, 1200 and 1300 UTC on 6 August 2006 from Exp. AR (Figure 11(a)) and Exp. AMR (Figure 11(b)). It is evident that aerosols/dust were first transported upward into the upper troposphere via the deep convection in the MCS (Figure 12) and then spread upstream via the elongated anvil/stratiform cloud region as the system was moving from east to west. For brevity, only the results from Exp. AMR are shown in Figure 12. This may explain the increase in cloud ice in the upper troposphere seen in Exps AM and AMR (Figure 10). Figure 13 shows cross-sections of model-predicted mean cloud hydrometeors between $12^{\circ} \mathrm{N}$ and $16^{\circ} \mathrm{N}$ at 0600,0900 and 1200 UTC on 6 August 2006 from all four experiments. The MCS moved slower when the aerosol direct effect was activated (Exps AR and AMR) than when it was not (Exps AM and Clean). It is also clear that the indirect effect resulted in a more elongated anvil cloud as depicted by the blue contours in Exps AM and AMR (bottom panels of Figure 13(a) and (c)) during the later stages of the MCS passage. Analysis of the cross-sections suggests that the aerosol direct effect has effectively delayed the onset of the precipitation event (also see the discussion for Figure 15 below) in this case. Lau and Kim (2006), through their elevated heat pump hypothesis, suggested that the aerosol direct effect could affect the onset of precipitation in seasonal precipitation events (e.g. monsoons). Results from this study suggest that it could also be true for MCSs with a life span of 2-3 days. As the MCS moved slower in Exp. AMR due to the aerosol direct effect, the onset of $\mathrm{CCN}$ and IN production from the transport of aerosols/dust was also delayed by roughly $2 \mathrm{~h}$ (Figure 14) with higher IN concentrations coinciding with the passage of the main part of the system at around $33 \mathrm{~h}$ (valid at 0900 UTC 6 August 2006); the impact on CCN, however, was minimal.

Figure 15 also reveals direct evidence of the delay in precipitation due to the aerosol direct effect. When aerosol effects were excluded (Exp. Clean, Figure 15(d)), the leading edge of the MCS entered the area after 0000 UTC 6 August, the main part of the system at around 0600 UTC 6 August, and the trailing edge after 1500 UTC 6 August. When only the aerosol indirect effect was activated (Exp. AM, Figure 15(a)), the delay in precipitation from the MCS was minimal. However, when the aerosol direct effect was activated regardless of the indirect effect (Exps AR and AMR) cloud hydrometeors increased between 1200 and 1800 UTC after having decreased before 1200 UTC (Figure 15(b) and (c)), which is consistent with the delay in the increases in CCN and IN concentrations shown in Figure 14. The delay in the cloud system moving into the area also resulted in a roughly $2 \mathrm{~h}$ delay in precipitation produced by the MCS in the area judging from the width of the red colour-shaded area in Figure 16(b) and (c).

\section{Summary and discussion}

In this study, an aerosol-microphysics-radiation coupling, using Goddard microphysics and radiation schemes, was successfully implemented into the NASA Unified WRF (NU-WRF). In order to study both the direct (in radiation) and indirect (in cloud microphysics) effects of aerosols, four different NU-WRFGOCART (WRF-Chem) coupled simulations were conducted (Exps AM, AR, AMR and Clean) for an MCS system that passed through the Niamey, Niger area on 6-7 August 2006 during an AMMA special observing period. As noted previously, conducting a reasonable simulation of MCSs in this region has been difficult as the initial and boundary conditions from the global analyses (e.g. NCEP GFS or ERA-Interim) covering this area are not as reliable as those covering other parts of the world. This study did not set out to fine-tune the simulations to achieve the best possible simulation as compared to the observations. The main focus of this study was to test the newly-implemented aerosol coupling in NU-WRF and to study the direct and indirect effects on MCS-type systems like the one simulated in this study. Considering the results from this study, the following conclusions are drawn:

- Although only results from Exp. AM were shown, the G-SDSU-calculated IR brightness temperatures of the convective cloud bands simulated from all four experiments on 6 August 2006 were comparable to the observed cloud band (as evidenced in Meteosat IR images) in terms of the overall location, although the timing appears to be delayed by a few hours. The life cycle of the MCS was relatively well produced with a northwest-southeast oriented cloud band but suffered the same deficiency as reported in Penide et al.(2010) as the simulated system moved a few hours slower than the observed. A direct rainfall comparison is problematic as there is no reliable rain-gauge network in the area. Therefore, the $24 \mathrm{~h}$ accumulated precipitation amounts derived from the MIT radar data at Niamey and TRMM data were adopted to provide a quantitative comparison of the model rainfall forecast. The results show that the experiment with only the aerosol indirect (microphysics) effect produced the best average rainfall forecast as compared with the rainfall estimated from TRMM and the MIT radar at Niamey.

- The aerosol direct effect (mainly by dust) had the biggest impact in the layer just above $200 \mathrm{hPa}$ near the cloud tops, roughly increasing the SW heating by about $0.8 \mathrm{~K} \mathrm{day}^{-1}$ at $150 \mathrm{hPa}$. It also affected LW cooling. The layer just below the cloud tops and where the strongest SW heating occurs (i.e. around $250 \mathrm{hPa}$ ) had the weakest LW cooling. Starting in this layer and continuing down through the rest of the column, LW cooling is increased by the presence of aerosols/dust inside the cloud. However, it is still not clear why the direct effect via the presence of aerosols/dust increased LW cooling in the column below the cloud tops. One possible explanation is that the presence of aerosols/dust altered the cloud structure and therefore the LW cooling.

- The combined results from all four experiments suggest that (i) higher aerosol/dust concentrations result in more $\mathrm{CCN}$ and IN and a subsequent increase in the amount of all cloud hydrometeors because of the microphysical indirect effect; and that (ii) the aerosol direct effect on radiation acts to reduce larger precipitation-sized cloud particles (i.e. rain, snow and graupel) in middle and lower cloud layers and increase the amount of small ice particles in upper-level cirrus cloud layer. The results also show increasing amounts of ice particles (cloud ice) with increasing aerosol/dust concentrations (i.e. more IN) due to strong convection. This agrees with past studies (Khain et al., 2009; Tao et al., 2012). 
(a)

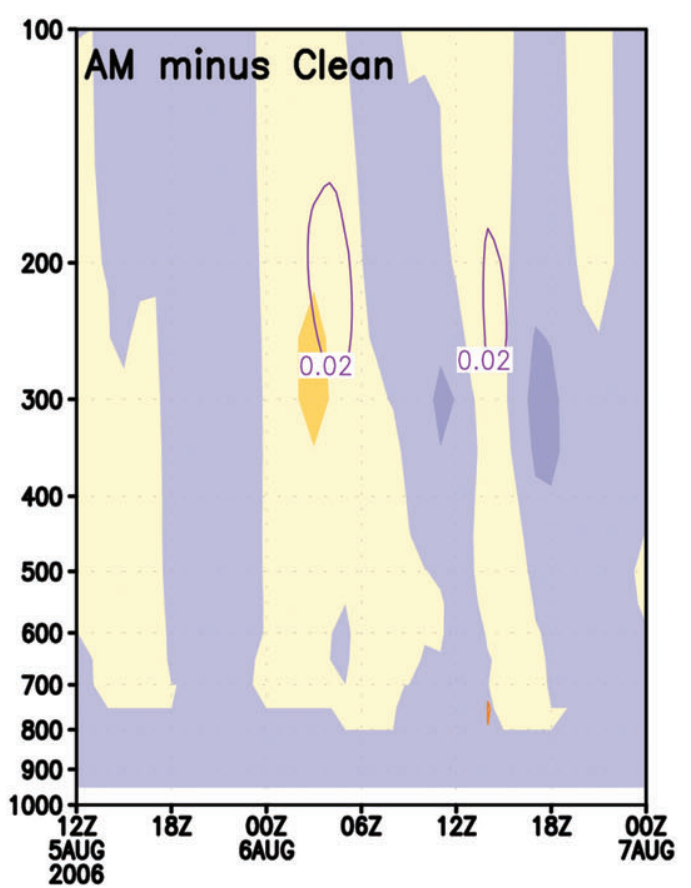

(c)

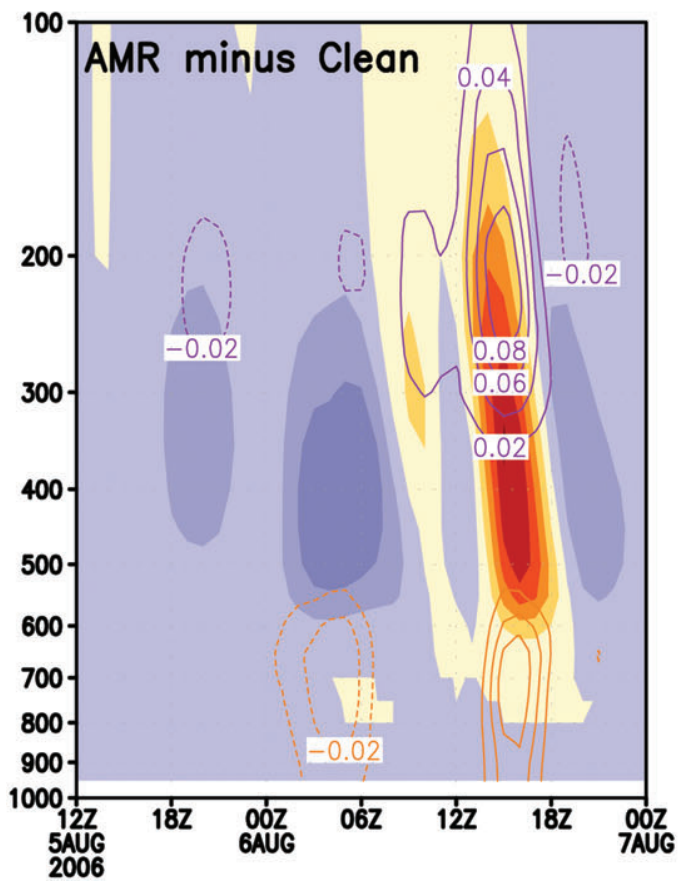

(b)

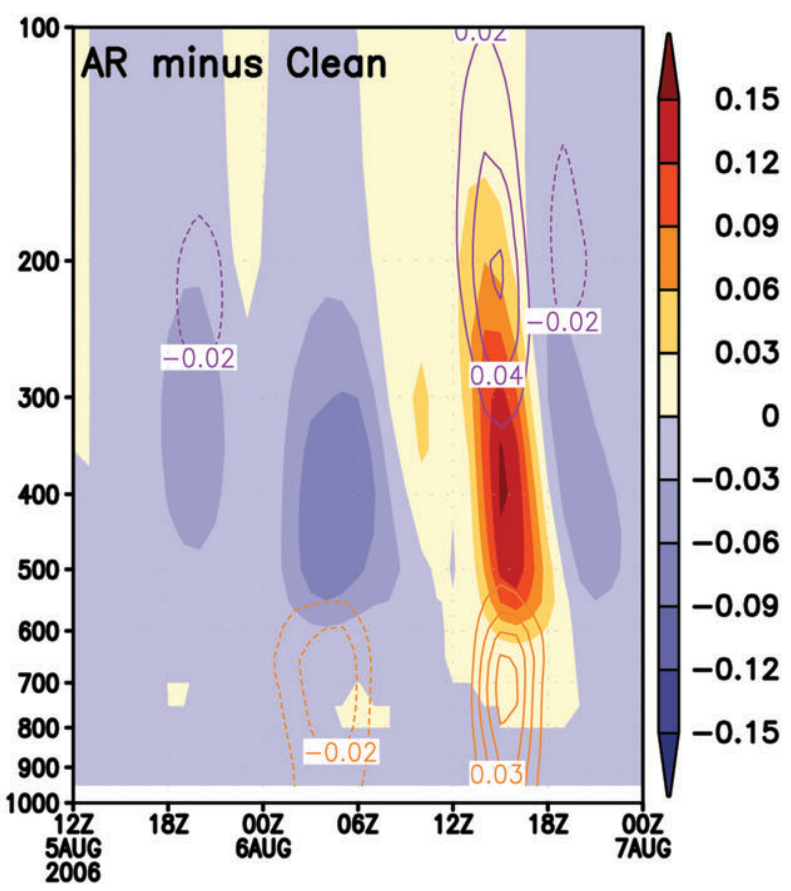

(d)

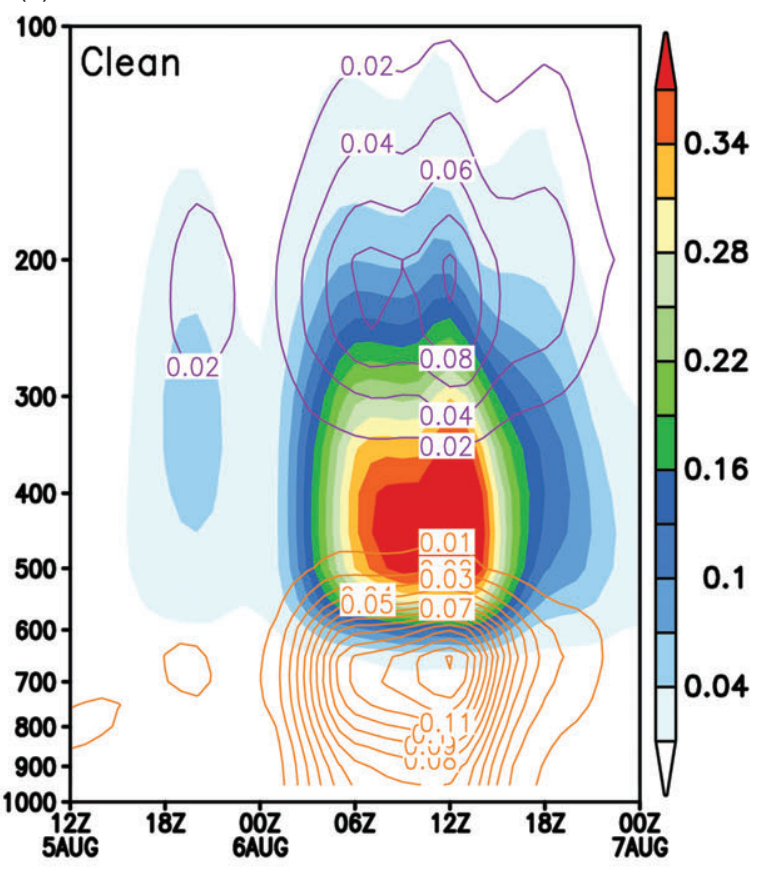

Figure 15. Time series of the difference in area-mean cloud hydrometeors between (a) Exp. AM, (b) Exp. AR, (c) Exp. AMR and Exp. Clean. Orange contours are for cloud plus rain, purple contours ice, and shading snow plus graupel; solid and dashed lines indicate positive and negative respectively. (d) Time series of area-mean cloud hydrometeor profiles from Exp. Clean. The averaging area is the same as for Figure 9.

- Aerosols/dust were first transported upward into the upper troposphere via the deep convection within the MCS before being spread upstream via the elongated anvil/stratiform cloud region as the MCS was moving from east to west. This result may explain the increase in ice in the upper troposphere when the aerosol indirect (microphysics) effect was activated. The MCS moved slower when the aerosol direct effect was activated than when it was not. The results also show that the microphysics indirect effect resulted in a larger, more elongated anvil/stratiform cloud.

- Overall, when only the aerosol indirect effect was activated, the delay in precipitation from the MCS was minimal. However, when the aerosol direct (radiation) effect was activated regardless of whether the indirect effect was activated, precipitation from the MCS was delayed by about $2 \mathrm{~h}$, consistent with the delay in the increases in
CCN and IN concentrations. The estimated $2 \mathrm{~h}$ delay in precipitation also agrees with the assessment by Penide et al.(2010). The results from this study suggest that the aerosol direct (radiation) effect could affect the onset of precipitation in MCSs with a life span of 2-3 days.

One of the goals in this study was to incorporate aerosol impacts into the Goddard one-moment microphysics scheme to take account for their first-order effects: namely, changing the raindrop number concentrations and cloud-to-rain and iceto-snow conversion rates without substantially increasing the computational burden. In this case-study, the aerosol indirect effect on CCN seems to be much smaller than on IN (Figure 14). This could be because of the use of a one-moment bulk scheme in the current Goddard microphysics scheme. CCN were calculated from the aerosol species predicted by GOCART based on the 

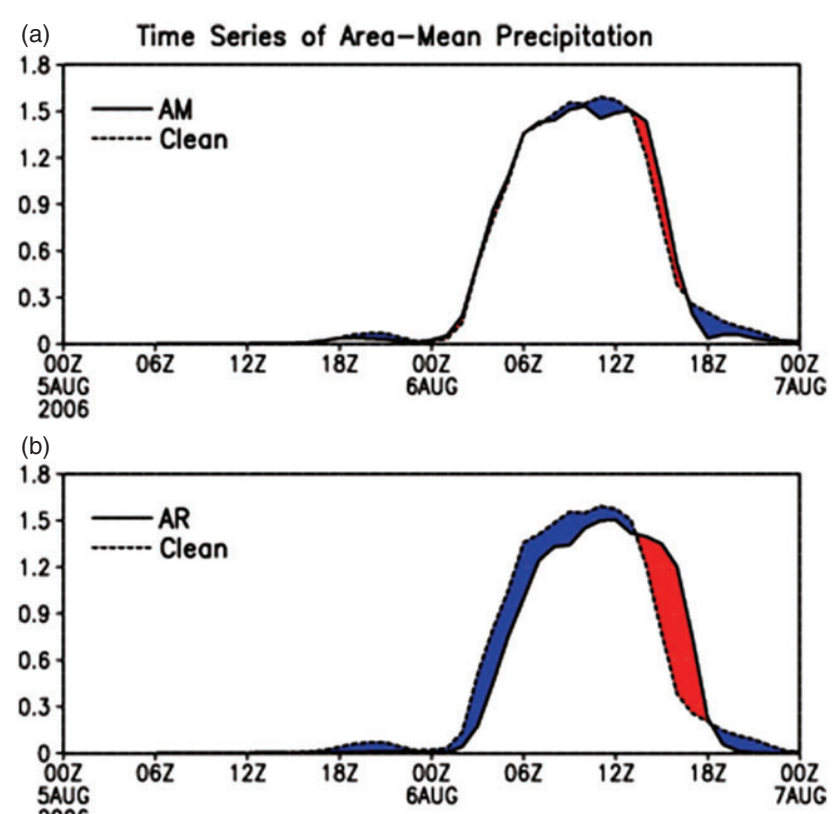

(c)

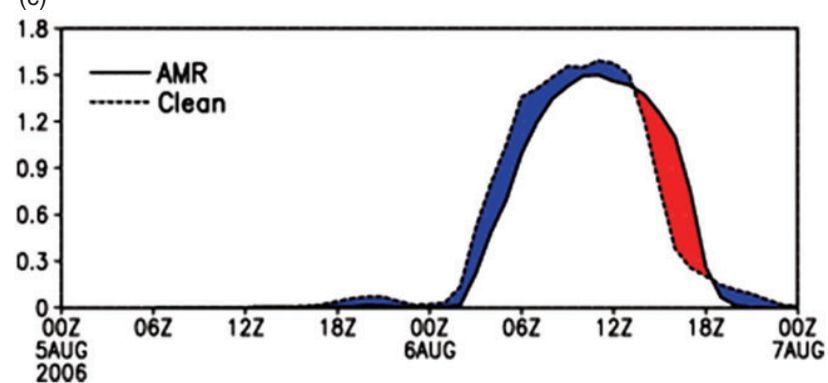

Figure 16. Time series of area-mean precipitation ( $\mathrm{mm}$ ) between (a) Exp. AM (b) Exp. AR, (c) Exp. AMR and Exp. Clean. Blue areas represent less precipitation than in Exp. Clean and red greater. The averaging area is the same as for Figure 9.

Koehler curve and then only used in the auto-conversion of cloud droplets to rain drops. A two-moment bulk scheme with a more complete aerosol indirect effect is being implemented into NU-WRF. A wet deposition scheme consistent with cloud microphysical fields and with below-rain wash out and in-rain scavenging of aerosol species is also being developed for the Goddard microphysics scheme. Results will be reported in a future publication.

\section{Acknowledgement}

This research effort is supported by the NASA headquarters Modeling, Analysis, and Prediction (MAP) Program and Interdisciplinary Sciences (IDS) Program. The authors are grateful to David Considine at NASA headquarters for his support of this research. The authors appreciate Kyu-Myong Kim of NASA GSFC and Morgan State University for his help on the data analysis. The authors also appreciate the useful discussion with Zhining Tao of USRA, Xiaowen Li of NASA GSFC and Morgan State University, and Shujia Zhou and Philip Hayes of Northrop Grumman Corporation.

\section{References}

Ackerman SA, Chung H. 1992. Radiative effects of airborne dust on regional energy budgets at the top of the atmosphere. J. Appl. Meteorol. 31: 223-233. Andreae MO, Rosenfeld D. 2008. Aerosol-cloud-precipitation interactions. Part 1. The nature and sources of cloud-active aerosols. Earth Sci. Rev. 89: 13-41.

Bangert M, Nenes A, Vogel B, Vogel H, Barahona D, Karydis VA, Kumar P, Kottmeier C, Blahak U. 2012. Saharan dust event impacts on cloud formation and radiation over western Europe. Atmos. Chem. Phys. 12: 4045-4063.

Bond TC, Streets DG, Yarber KF, Nelson SM, Woo J-H, Klimont Z. 2004. A technology-based global inventory of black and organic carbon emissions from combustion. J. Geophys. Res. 109: D14203, doi: 10.1029/2003JD003697.
Brindley HE, Russell JE. 2008. Assessing the errors in shortwave radiative fluxes inferred from the Geostationary Earth Radiation Budget (GERB) instrument in the presence of dust aerosol. J. Appl. Meteorol. Clim. 47: 1659-1680.

Brindley HE, Russell JE. 2009. An assessment of Saharan dust loading and the corresponding cloud-free longwave direct radiative effect from geostationary satellite observations. J. Geophys. Res. 114: D23201, doi: 10.1029/2008JD011635.

Carlson TN, Benjamin SG. 1980. Radiative heating rates for Saharan dust. J. Atmos. Sci. 37: 193-213.

Chen F, Dudhia J. 2001. Coupling an advanced land surface-hydrology model with the Penn State-NCAR MM5 modeling system. Part I: Model implementation and sensitivity. Mon. Weather Rev. 129: 569-585.

Chen S-H, Wang SH, Waylonis M. 2010. Modification of Saharan air layer and environmental shear over the eastern Atlantic Ocean by dust-radiation effects. J. Geophys. Res. 115: D21202, doi: 10.1029/2010JD014158.

Chin M, Rood RB, Lin S-J, Miller J-F, Thompson AM. 2000. Atmospheric sulfur cycle simulated in the global model GOCART: Model description and global properties. J. Geophys. Res. 105: 24671-24687.

Chin M, Ginoux P, Lucchesi R, Huebert B, Weber R, Anderson T, Masonis S, Blomquist B, Bandy A, Thornton D. 2003. A global aerosol model forecast for the ACE-Asia field experiment. J. Geophys. Res. 108: 8654, doi: 10.1029/2003JD003642.

Chin M, Chu DA, Levy R, Remer LA, Kaufman YJ, Holben BN, Eck T, Ginoux P. 2004. Aerosol distribution in the Northern Hemisphere during ACEAsia: Results from global model, satellite observations, and sunphotometer measurements. J. Geophys. Res. 109: D23S90, doi: 10.1029/2004JD004829.

Chin M, Diehl T, Ginoux P, Malm W. 2007. Intercontinental transport of pollution and dust aerosols: Implications for regional air quality. Atmos. Chem. Phys. 7: 5501-5517.

Chin M, Diehl T, Dubovik O, Eck TF, Holben BN, Sinyuk A, Streets DG. 2009. Light absorption by pollution, dust, and biomass burning aerosols: A global model study and evaluation with AERONET measurements. Ann. Geophys. 27: 3439-3464.

Chou M-D, Suarez MJ. 1999. 'A solar radiation parameterization for atmospheric studies'. NASA Technical report NASA/TM-1999-10460, Vol. 15.

Chou M-D, Suarez MJ. 2001. 'A thermal infrared radiation parameterization for atmospheric studies'. NASA Technical report NASA/TM-2001-104606, Vol. 19.

D'Amato N, Lebel T. 1998. On the characteristics of the rainfall events in the Sahel with a view to the analysis of climatic variability. Int. J. Climatol. 18: 955-974.

Dee DP, Uppala SM, Simmons AJ, Berrisford P, Poli P, Kobayashi S, Andrae U, Balmaseda MA, Balsamo G, Bauer P, Bechtold P, Beljaars ACM, van de Berg L, Bidlot J, Bormann N, Delsol C, Dragani R, Fuentes M, Geer AJ, Haimberger L, Healy SB, Hersbach H, Hólm EV, Isaksen L, Kållberg P, Köhler M, Matricardi M, McNally AP, Monge-Sanz BM, Morcrette JJ, Park B-K, Peubey C, de Rosnay P, Tavolato C, Thépaut J-N, Vitart F. 2011. The ERA-Interim reanalysis: Configuration and performance of the data assimilation system. Q. J. R. Meteorol. Soc. 137: 553-597.

Demott PJ, Prenni AJ, Liu X, Kreidenweis SM, Petters MD, Twohy CH, Richardson MS, Eidhammer T, Rogers DC. 2010. Predicting global atmospheric ice nuclei distributions and their impacts on climate. Proc. Natl. Acad. Sci. 107: 11217-11222.

Fink AH, Vincent DG, Ermert V. 2006. Rainfall types in the West African Sudanian zone during the summer monsoon 2002. Mon. Weather Rev. 134: 2143-2164.

Fouquart Y, Bonnel B, Brogniez G, Buriez JC, Smith L, Morcrette J-J, Cerf A. 1987. Observations of Saharan aerosols: Results of ECLATS field experiment. Part II: Broadband radiative characteristics of the aerosols and vertical radiative flux divergence. J. Clim. Appl. Meteorol. 26: 38-52.

Ginoux P, Chin M, Tegen I, Prospero J, Holben B, Dubovik O, Lin S-J. 2001. Sources and distributions of dust aerosols simulated with the GOCART model. J. Geophys. Res. 106: 20255-20273.

Ginoux P, Prospero JM, Torres O, Chin M. 2004. Long-term simulation of global dust distribution with the GOCART model: Correlation with North Atlantic Oscillation. Environ. Modell. Softw. 19: 113-128.

Grell GA, Dévényi D. 2002. A generalized approach to parameterizing convection combining ensemble and data assimilation techniques. Geophys. Res. Lett. 29: 1693, doi: 10.1029/2002GL015311.

Guy N, Zeng XP, Rutledge SA, Tao W-K. 2013. Comparing the convective structure and microphysics in two Sahelian mesoscale convective systems: Radar observations and CRM simulations. Mon. Weather Rev. 141: $582-601$.

Huntrieser H, Schlager H, Lichtenstern M, Stock P, Hamburger T, Holler H, Schmidt K, Betz H-D, Ulanovsky A, Ravegnani F. 2011. Mesoscale convective systems observed during AMMA and their impact on the $\mathrm{NO}_{\mathrm{x}}$ and $\mathrm{O}_{3}$ budget over West Africa. Atmos. Chem. Phys. 11: 2503-2536.

Janicot S, Thorncroft CD, Ali A, Asencio N, Berry GJ, Bock O, Bourlès B, Caniaux G, Chauvin F, Deme A, Kergoat L, Lafore J-P, Lavaysse C, Lebel T, Marticoréna B, Mounier F, Nédélec P, Redelsperger J-L, Ravegnani F, Reeves CE, Roca R, De Rosnay P, Schlager H, Sultan B, Tomasini M, Ulanovsky A. 2008. Large-scale overview of the summer monsoon over West Africa during the AMMA field experiment in 2006. Ann. Geophys. 26: 2569-2595.

Johnson BT, Heese B, McFarlane SA, Chazette P, Jones A, Bellouin N. 2008. Vertical distribution and radiative effects of mineral dust and biomass burning aerosol over West Africa during DABEX. J. Geophys. Res. 113: D00C12, doi: 10.1029/2008JD009848. 
Khain AP. 2009. Notes on state-of-the art investigations of aerosol effects on precipitation: A critical review. Environ. Res. Lett. 4: 015004, doi: 10.1088/1748-9326/4/1/015004

Khain A, Lynn B. 2009. Simulation of a supercell storm in clean and dirty atmosphere using weather research and forecast model with spectral bin microphysics. J. Geophys. Res. 114: D19209, doi: 10.1029/2009JD011827.

Khain A, Pokrovsky A, Pinsky M, Seifert A, Phillips V. 2004. Effects of atmospheric aerosols on deep convective clouds as seen from simulations using a spectral microphysics mixed-phase cumulus cloud model. Part 1: Model description. J. Atmos. Sci. 61: 2963-2982.

Khain A, Leung LR, Lynn B, Ghan S. 2009. Effects of aerosols on the dynamics and microphysics of squall lines simulated by spectral bin and bulk parameterization schemes. J. Geophys. Res. 114: D22203, doi: 10.1029/2009JD011902.

Khain A, Lynn B, Dudhia J. 2010. Aerosol effects on intensity of landfalling hurricanes as seen from simulations with WRF model with spectral bin microphysics. J. Atmos. Sci. 67: 365-384.

Kinne S, Schulz M, Textor C, Guibert S, Balkanski Y, Bauer SE, Berntsen T, Berglen TF, Boucher O, Chin M, Collins W, Dentener F, Diehl T, Easter R, Feichter J, Fillmore D, Ghan S, Ginoux P, Gong S, Grini A, Hendricks J, Herzog M, Horowitz L, Isaksen I, Iversen T, Kirkevåg A, Kloster S, Koch D, Kristjansson JE, Krol M, Lauer A, Lamarque JF, Lesins G, Liu X, Lohmann U, Montanaro V, Myhre G, Penner J, Pitari G, Reddy S, Seland O, Stier P, Takemura T, Tie X. 2006. An AeroCom initial assessment - optical properties in aerosol component modules of global models. Atmos. Chem. Phys. 6: 1815-1834.

Koehler KA, Kreidenweis SM, DeMott PJ, Prenni AJ, Carrico CM, Ervens B, Feingold G. 2006. Water activity and activation diameters from hygroscopicity data. Part II: Application to organic species. Atmos. Chem. Phys. 6: 795-809.

Kumar SV, Peters-Lidard CD, Tian Y, Geiger J, Houser PR, Olden S, Lighty L, Eastman JL, Dirmeyer P, Doty B, Adams J, Wood E, Sheffield J. 2006. LIS - An interoperable framework for high resolution land surface modeling. Environ. Modell. Softw. 21: 1402-1415.

Kumar SV, Peters-Lidard CD, Eastman JL, Tao W-K. 2007. An integrated high resolution hydrometeorological modeling testbed using LIS and WRF. Environ. Modell. Softw. 23: 169-181.

Lana A, Bell TG, Simó R, Vallina SM, Ballabrera-Poy J, Kettle AJ, Dachs J, Bopp L, Saltzman ES, Stefels J, Johnson JE, Liss PS. 2011. An updated climatology of surface dimethlysulfide concentrations and emission fluxes in the global ocean. Global Biogeochem. Cycles 25: GB1004, doi: 10.1029/2010GB003850.

Lang S, Tao W-K, Cifelli R, Olson W, Halverson J, Rutledge S, Simpson J. 2007. Improving simulations of convective systems from TRMM LBA: Easterly and westerly regimes. J. Atmos. Sci. 64: 1141-1164.

Lang SE, Tao W-K, Zeng X, Li Y. 2011. Reducing the biases in simulated radar reflectivities from a bulk microphysics scheme: Tropical convective systems. J. Atmos. Sci. 68: 2306-2320.

Lau K-M, Kim K-M. 2006. Observational relationships between aerosol and Asian monsoon rainfall, and circulation. Geophys. Res. Lett. 33: L21810, doi: 10.1029/2006GL027546.

Laurent H, D'Amato N, Lebel T. 1998. How important is the contribution of the mesoscale convective complexes to the Sahelian rainfall? Phys. Chem. Earth 23: 629-633.

Le Barbé L, Lebel T. 1997. Rainfall climatology of the HAPEX-Sahel region during the years 1950-1990. J. Hydrol. 188-189: 43-73.

Lebel T, Parker DJ, Flamant C, Bourles B, Marticorena B, Mougin E, Peugeot C, Diedhiou A, Haywood JM, Ngamini JB, Polcher J, Redelsperger JL, Thorncroft CD. 2009. The AMMA field campaigns: Multiscale and multidisciplinary observations in the West African region. Q. J. R. Meteorol. Soc. 136: 8-33.

Levin Z, Cotton WR. 2009. Aerosol Pollution Impact on Precipitation: A Scientific Review. Springer: New York.

Li F, Vogelmann AM, Ramanathan V. 2004. Saharan dust aerosol radiative forcing measured from space. J. Clim. 17: 2558-2571.

Li G, Wang Y, Zhang R. 2008. Implementation of a two- moment bulk microphysics scheme to the WRF model to investigate aerosol-cloud interaction. J. Geophys. Res. 113: D15211, doi: 10.1029/2007JD009361.

Li G, Wang Y, Lee K-H, Diao Y, Zhang R. 2009. Impacts of aerosols on development and precipitation of a mesoscale squall line. J. Geophys. Res. 114: D17205, doi: 10.1029/2008JD011581.

Lin Y-L, Farley RD, Orville HD. 1983. Bulk parameterization of the snow field in a cloud model. J. Clim. Appl. Meteorol. 22: 1065-1092.

Liu Y, Daum PH. 2004. Parameterization of the autoconversion process. Part I: Analytical formulation of the Kessler-type parameterizations. J. Atmos. Sci. 61: $1539-1548$

Lynn B, Khain A, Rosenfeld D, Woodley WL. 2007. Effects of aerosols on precipitation from orographic clouds. J. Geophys. Res. 112: D10225, doi: 10.1029/2006JD007537.

McCumber M, Tao W-K, Simpson J, Penc R, Soong S-T. 1991. Comparison of ice-phase microphysical parameterization schemes using numerical simulations of convection. J. Appl. Meteorol. 30: 985-1004.

Mallet M, Tulet P, Serca D, Solmon F, Dubovik O, Pelon J, Pont V, Thouron O. 2009. Impact of dust aerosols on the radiative budget, surface heat fluxes, heating rate profiles and convective activity over West Africa during March 2006. Chem. Phys. 9: 7143-7160.

Masunaga H, Matsui T, Tao W-K, Hou AY, Kummerow C, Nakajima T, Bauer P, Olson W, Sekiguchi M, Nakajima TY. 2011. Satellite data simulator unit: Multi-sensor and multi-frequency satellite simulator package. Bull. Am. Meteorol. Soc. 91: 1625-1632, doi: 10.1175/2010BAMS2809.1.
Mathon V, Laurent H, Lebel T. 2002. Mesoscale convective system rainfall in the Sahel. J. Appl. Meteorol. Clim. 41: 1081-1092.

Matsui T, Zeng X, Tao W-K, Masunaga H, Olson W, Lang S. 2009. Evaluation of long-term cloud-resolving model simulations using satellite radiance observations and multifrequency satellite simulators. J. Atmos. Oceanic Technol. 26: 1261-1274.

Mellor GL, Yamada T. 1982. Development of a turbulence closure model for geophysical fluid problems. Rev. Geophys. 20: 851-875, doi: 10.1029/RG020i004p00851.

Michalakes J, Dudhia J, Gill D, Henderson T, Klemp J, Skamarock W, Wang W. 2004. The Weather Research and Forecast Model: Software architecture and performance. Proceedings 11th ECMWF Workshop on the Use of High Performance Computing in Meteorology, Reading, UK, 25-29 October 2004: 18 pp. World Scientific. http://www.ecmwf. int/newsevents/meetings/workshops/2004/high_performance_computing11th/pdf/John_Michalakes.pdf.

Monin AS, Obukhov AM. 1954. Basic laws of turbulent mixing in the surface layer of the atmosphere. Contrib. Geophys. Inst. Acad. Sci. USSR 24: 163-187 (in Russian).

Mu M, Randerson JT, van der Werf GR, Giglio L, Kasibhatla P, Morton D, Collatz GJ, Defries RS, Hyer EJ, Prins EM, Griffith DWT, Wunch D, Toon GC, Sherlock V, Wennberg PO. 2011. Daily and 3-hourly variability in global fire emissions and consequences for atmospheric model predictions of carbon monoxide. J. Geophys. Res. 116: D24303, doi: 10.1029/2011JD0 16245.

Nicholson S. 2009. A revised picture of the structure of the 'monsoon' and land ITCZ over West Africa. Clim. Dyn. 32: 1155-1171.

Parker DJ, Burton RR, Diongue-Niang A, Ellis RJ, Felton M, Taylor CM, Thorncroft CD, Bessemoulin P, Tompkins AM. 2005. The diurnal cycle of the West African monsoon circulation. Q. J. R. Meteorol. Soc. 131: 2839-2860.

Penide G, Giraud V, Bouniol D, Dubuisson P, Duroure C, Protat A, Cautenet S. 2010. Numerical simulation of the 7 to 9 September 2006 AMMA mesoscale convective system: Evaluation of the dynamics and cloud microphysics using synthetic observations. Q. J. R. Meteorol. Soc. 136: 304-322.

Powell SW, Houze RA Jr, Kumar A, McFarlane SA. 2012. Comparison of simulated and observed continental tropical anvil clouds and their radiative heating profiles. J. Atmos. Sci. 69: 2662-2680.

Redelsperger J-L, Diongue A, Diedhiou A, Ceron J-P, Diop M, Gueremy J-F, Lafore J-P. 2002. Multi-scale description of a Sahelian synoptic weather system representative of the West African monsoon. Q. J. R. Meteorol. Soc. 128: $1229-1257$.

Rosenfeld D, Lohmann U, Raga GB, O’Dowd CD, Kulmala M, Fuzzi S, Reissell A, Andreae MO. 2008. Flood of drought: How do aerosols affect precipitation? Science 321: 1309-1313.

Rotman DA, Tannahill JR, Kinnison DE, Connell PS, Bergmann D, Proctor D, Rodriguez JM, Lin SJ, Rood RB, Prather MJ, Rasch PJ, Considine DB, Ramaroson R, Kawa SR. 2001. The Global Modeling Initiative assessment model: Model description, integration and testing of the transport shell. J. Geophys. Res. 106: 1669-1691.

Russell B, Williams ER, Gosset M, Cazenave F, Descroix L, Guy N, Lebel T, Ali A, Metayer F, Quantin G. 2010. Radar/rain-gauge comparisons on squall lines in Niamey, Niger for the AMMA. Q. J. R. Meteorol. Soc. 136(S1): 289-303, DOI: 10.1002/qj.548.

Ruti PM, Williams JE, Hourdin F, Guichard F, Boone A, Van Velthoven P, Favot F, Musat I, Rummukainen M, Domínguez M, Gaertner MÁ, Lafore JP, Losada T, Rodriguez de Fonseca MB, Polcher J, Giorgi F, Xue Y, Bouarar I, Law K, Josse B, Barret B, Yang X, Mari C, Traore AK. 2011. The West African climate system: A review of the AMMA model intercomparison initiatives. Atmos. Sci. Lett. 12: 116-122, doi: 10.1002/asl.305.

Rutledge SA, Hobbs PV. 1984. The mesoscale and microscale structure and organization of clouds and precipitation in mid-latitude cyclones. Part XII: A diagnostic modeling study of precipitation development in narrow cold frontal rainbands. J. Atmos. Sci. 41: 2949-2972.

Shi JJ, Tao W-K, Matsui T, Cifelli R, Hou A, Lang S, Tokey A, Wang N-Y, PetersLidard C, Jackson G, Rutledge S, Petersen W. 2010. WRF simulations of the 20-22 January 2007 snow events over eastern Canada: Comparison with in-situ and satellite observations. J. Appl. Meteorol. Clim. 49: 2246-2266.

Skamarock WC, Klemp JB, Dudhia J, Gill DO, Barker DM, Duda MG, Huang XY, Powers JG. 2008. 'A description of the advanced research WRF version 3'. NCAR Technical Note NCAR/TN-4751STR. NCAR: Boulder, CO. http://www.mmm.ucar.edu/wrf/users/docs/arw_v3.pdf.

Smoydzin L, Teller A, Tost H, Fnais M, Lelieveld J. 2012. Impact of minera dust on cloud formation in a Saharan outflow region. Atmos. Chem. Phys. 12: $11383-11393$

Stanelle T, Vogel B, Vogel H, Baumer D, Kottmeier C. 2010. Feedback between dust particles and atmospheric processes over West Africa during dust episodes in March 2006 and June 2007. Chem. Phys. 10: $10771-10788$

Streets DG, Bond CT, Lee T, Jang C. 2004. On the future of carbonaceous aerosol emissions. J. Geophys. Res. 109: D24212, doi: 10.1029/2004JD004902.

Streets DG, Yan F, Chin M, Diehl T, Mahowald N, Schultz M, Wild M, Wu Y, Yu C. 2009. Anthropogenic and natural contributions to regional trends in aerosol optical depth, 1980-2006. J. Geophys. Res. 114: D00D18, doi: 10.1029/2008JD011624

Tao W-K, Simpson J, Baker D, Braun S, Chou M-D, Ferrier B, Johnson D, Khain A, Lang S, Lynn B, Shie C-L, Starr D, Sui C-H, Wang Y, Wetzel P. 2003. 
Microphysics, radiation and surface processes in the Goddard Cumulus Ensemble (GCE) model, a Special Issue on Non-hydrostatic Mesoscale Modeling. Meteorol. Atmos. Phys. 82: 97-137.

Tao W-K, Li X, Khain A, Matsui T, Lang S, Simpson J. 2007. Role of atmospheric aerosol concentration on deep convective precipitation: Cloud-resolving model simulations. J. Geophys. Res. 112: D24S18, doi: 10.1029/2007JD008728.

Tao W-K, Chen J-P, Li Z, Wang C, Zhang C. 2012. Impact of aerosols on convective clouds and precipitation. Rev. Geophys. 50: RG2001, doi: 10.1029/2011RG000369.

Thorncroft CD, Haile M. 1995. The mean dynamical and thermodynamic fields for July 1989 over tropical North Africa and their relationship to convective storm activity. Mon. Weather Rev. 123: 3016-3031.

Wang C, Jeong GR, Mahowald N. 2009. Particulate absorption of solar radiation: Anthropogenic aerosols vs. dust. Atmos. Chem. Phys. 9: 3935-3945.

Yu H, Remer LA, Chin M, Bian H, Kleidman RG, Diehl T. 2008. A satellitebased assessment of trans-Pacific transport of pollution aerosol. J. Geophys. Res. 113: D14S12, doi: 10.1029/2007JD009349.

Zhu A, Ramanathan V, Li F, Kim D. 2007. Dust plumes over the Pacific, Indian, and Atlantic Oceans: Climatology and radiative impact. J. Geophys. Res. 112: D16208, doi: 10.1029/2007JD008427. 